\title{
Globoecopragmatism: How to Think (and How Not to Think) About Trade and the Environment
}

\author{
Robert F. Blomquist
}

\section{INTRODUCTION}

Globalization-for better or for worse-is the great politicaleconomic-legal issue of the first part of the twenty-first century. Thoughtful commentators in recent years have started to respond to the strident critics of globalization who tend to blame expanded international trade and direct foreign investment for a host of social ills-from American job losses and a race to the bottom in wages to attacks on environmental laws to compromised health standards.

The principal thesis of this Article is that globalization is not as bad for the environment as its critics contend and, in many ways, is good for the environment in the long term. Yet, there are pragmatic steps that the international community can take to more intelligently ameliorate tradeinduced environmental degradation and to better balance free trade with ecological protection.

Make no mistake, this Article has attitude. I do not pretend to have selected an objective, scientific sample of writings on trade and the environment. Rather, I have chosen material which I find to be interesting. My objective is to take apart the work of six recently published pieces on trade and the environment and then to synthesize the most robust insights contained in these publications into various pragmatic principles that will provoke a debate among scholars and policymakers on a global, practical, trade-enhancing, environmentally protective legal strategy for the future. My name for this overarching framework for thinking clearly and wisely about trade and environmental issues also has attitude: with an eye toward the elegant and an ear toward the rhythmic, I suggest the name globoecopragmatism. In the course of my discussion, as I deem it useful, and helpful, I will employ the views of other scholars.

Professor of Law, Valparaiso University School of Law; B.S., University of Pennsylvania (Wharton School), 1973; J.D., Cornell University, 1977. My thanks go to: Jim Chen, Dan Farber, Sanford Gaines, and Doug Kysar for helpful comments regarding an earlier draft. 
The three-part structure of the remainder of this Article is as follows. First, in Part II, I will summarize and discuss some key recent literature of environmental critics of globalization. ${ }^{1}$ Second, in Part III, I will review and analyze some major up-to-date defenses by globalization optimists to the environmental critics. ${ }^{2}$ Finally, in Part IV, synthesizing the edifying views of both globalization critics and globalization optimists, while building on the work of other theorists, I sketch the elements of a practical, trade-enhancing, environmentally protective legal strategy that I call globoecopragmatism; this discussion includes "the Blomquist Funnel of Pragmatism on Global Trade and the Environment," which incorporates seventeen principles of globoecopragmatism - ranging from the most concrete considerations to the most abstract inquiries.

\section{ENVIRONMENTAL CRITICS OF GLOBALIZATION}

\section{A. Peter Singer's Ethical Jeremiad}

In his provocative book, One World, ${ }^{4}$ Princeton bioethicist Peter Singer puts forth a call for "a larger perspective than that of national selfinterest" in living life in the new century-what he encapsulates with his call for "an ethical perspective on globalization.",

Singer starts his book with a startling linkage between $9 / 11$ and emissions of carbon dioxide from automobiles:

1. See infra notes 4-102 and accompanying text (discussing recent literature of environmental critics of globalization)

2. See infra notes 103-261 and accompanying text (analyzing defenses by globalization optimists to the environmental critics).

3. See infra notes 262-318 and accompanying text (giving principles of globoecopragmatism). In the last few years there has been an explosion of books on globalization, trade, and the environment. This corpus of writings should be analyzed and synthesized into the globoecopragmatism framework discussed in this Article. I have these books neatly stacked in an empty Guinness Extra Stout box in my office - to be read, studied, and incorporated into my workin-progress globoecopragmatism model in the future. See generally NATHALIE BERNASCONIOSTERWALDER ET AL., ENVIRONMENT AND TRAdE: A Guide tO WTO JuRISPRUdENCE (2005); SCOTT C. BRADFORD \& Robert Z. LAWRENCE, Has Globalization Gone FAR ENOUgh?: The Costs of Fragmented Markets (2004); I. M. Destler, American Trade Politics (4th ed. 2005); Free Trade Agreements: U.S. StRategies AND Priorities (Jeffrey J. Schott ed., 2004); GreENING THE AMERICAS: NAFTA's Lessons For Hemispheric Trade (Carolyn L. Deere \& Daniel C. Esty eds., 2002); Douglas A. Irwin, FreE Trade Under Fire (2d ed. 2005); PhilipPe Legrain, Open World: The TRUth About Globalization (2004); Martin Wolf, Why GLOBALIZATION WORKS (2004)

4. Peter Singer, One World: The Ethics of Globalization (2d ed. 2004).

5. Id. at ix.

6. Id. 
Consider two aspects of globalization: first, planes exploding as they slam into the World Trade Center, and second, the emission of carbon dioxide from the exhausts of gas-guzzling sport utility vehicles. One brought instant death and left unforgettable images that were watched on television screens all over the world; the other makes a contribution to climate change that can be detected only by scientific instruments. Yet both are indications of the way in which we are now one world, and the more subtle changes to which sport utility vehicles owners unintentionally contribute will almost certainly kill far more people than the highly visible one. When people in rich nations switch to vehicles that use more fuel than the cars they used to drive, they contribute to changes in the climate of Mozambique or Bangladeshchanges that may cause crops to fail, sea levels to rise, and tropical diseases to spread. As scientists pile up the evidence that continuing greenhouse gas emissions will imperil millions of lives, the leader of the nation that emits the largest share of these gases [(President George W. Bush)] has said: "We will not do anything that harms our economy, because first things first are the people who live in America.",

A striking characteristic of Singer's opening salvo, quoted above, is its lack of reference to critical fairness concepts that every lawyer is familiar with: causation-in-fact and proximate causation. Underlying these causation concepts are social policies of fault and proportionality that the common law has been concerned with down through the centuries. Thus, regarding causation-in-fact, Singer ignores four specific problems. First, he blows off the question of "scientific connection" between "the defendant's acts and the plaintiff's injury, frequently a problem in toxic tort cases." "His presupposition seems to suggest that as long as there is any theoretical scientific linkage between cause and effect (carbon emissions from SUVs in America and increased global warming leading to crop failures, sea level rises, or tropical diseases in Mozambique or Bangladesh) the "contribution" to the cause-however de minimis or attenuated - is blameworthy. ${ }^{9}$ Second, Singer ignores the "who is the cause" problem ${ }^{10}$ in his archetypal hypothetical. This type of factual causation "problem occurs when the plaintiff is definitely injured by someone or something but cannot produce evidence to indicate which person among many was the injurer."11 Third, Singer overlooks in the

7. Id. at $1-2$.

8. DAN B. DobBs, The Law OF TORTS 405 (2000).

9. Cf. Margaret A. Berger, Eliminating General Causation: Notes Towards a New Theory of Justice and Toxic Torts, 97 Colum. L. REV. 2117 (1997) (arguing that because of the practical difficulties of producing acceptable evidence in complex, toxic tort cases, as a matter of policy some relief from the evidentiary burdens should be allowed in special cases).

10. DoBBS, supra note 8, at 406.

11. Id. 
aforementioned excerpt the "would safe behavior have avoided injury" problem. ${ }^{12}$ This cause-in-fact variation "cannot be resolved by medical or scientific evidence or by proving which among several defendants was the author of the plaintiff's harm."13 As explained in a recent treatise on tort law:

\begin{abstract}
Suppose the defendant does not check his rear view mirror before backing up and in consequence he backs over a child squatting behind the car. The defendant is negligent - he should have checked the mirror - but the critical point for a cause in fact argument is that he would not have avoided the injury by checking the mirror, since that would not have revealed the squatting child. Courts say in this kind of case that the defendant's negligence was not a cause in fact of the harm and that he is not liable.
\end{abstract}

So Singer fails to consider the would safe behavior have avoided injury problem by not discussing practical estimates about whether the substantial carbon emissions from coal-fired electrical generators in China, India, and Russia would have led to the same tropical diseases, flooding, and crop failure in Bangladesh and Mozambique - regardless of the American SUV emissions. Fourth, Singer turns a blind eye to the "what harm was caused" problem. ${ }^{15}$ Indeed, "[i]n some instances it is appropriate to apportion harm to causes, that is, to hold a defendant liable for a portion of the plaintiff's harm but not all of it." 16 This "is most obviously the case when one defendant breaks the plaintiff's arm and another defendant, acting independently, breaks the plaintiff's leg. Apportionment problems turn both on proof of facts-who caused what?-and also on several kinds of legal policy."17

Singer, likewise, turns his back on fundamental conceptions of proximate causation. First, he leaves out "practical concerns" in his opening metaphor of the problems of globalization associated with American SUV carbon emissions. "Without a proximate cause limit, liability . . . would go on forever, one harm leading endlessly to others."18 Alas, without practical proximate cause stopping points, we can imagine the following scary scenario: "The negligently made vacuum requires a trip to the repair shop, which leads the user to an auto

\footnotetext{
12. Id. at 407 .

13. Id.

14. Id.

15. Id.

16. $I d$.

17. $I d$.

18. Id. at 445
} 
accident, which leads to medical attention, which leads to another injury, which leads to loss of a job, and so on, more or less without end."19

Singer's main environmental criticism of globalization is contained in a chapter entitled "One Atmosphere.", He describes "[t]he [p]roblem" of atmospheric pollution as the archetypal illustration "of the need for human beings to act globally." 21 According to his view, "[g]etting rid of CFCs [chlorofluorocarbons] has turned out to be just the curtain raiser" of the world environmental drama; "the main event is climate change, or global warming.,"2 Singer acknowledges "the pioneering achievement of those who brought about the Montreal Protocol," phasing out industrial production of CFCs that were scientifically shown to threaten the stratospheric ozone shield. $\mathrm{He}$ claims, however, that this achievement of international diplomacy "was not so difficult" to bring about since "CFCs can be replaced in all their uses at relatively little cost, and the solution to the problem is simply to stop producing them." ${ }^{23}$ As he opines: "Climate change is a very different matter." ${ }^{24}$ After citing recent studies that show a risk of moderate heat rises over the next century, attributable to human actions, Singer tries to take another leap across the chasm of causation with the following normative conclusion:

All of this forces us to think differently about our ethics. Our value system evolved in circumstances in which the atmosphere, like the oceans, seemed an unlimited resource, and responsibilities and harms were generally clear and well defined. If someone hit someone else, it was clear who had done what. Now the twin problems of the ozone hole and of climate change have revealed bizarre new ways of killing people. By spraying deodorant at your armpit in your New York apartment, you could, if you use an aerosol spray propelled by CFCs, be contributing to the skin cancer deaths, many years later, of people living in ... Chile. By driving your car, you could be releasing carbon dioxide that is part of a causal chain leading to lethal floods in Bangladesh. How can we adjust our ethics to take account of this new situation? ${ }^{25}$

What Singer's analysis lacks is nuance and proportionality. Indeed, underlying his entire ethical scrutiny of the United States's unwillingness

19. Id

20. SINGER, supra note 4 , at $14-50$.

21. Id. at 14 .

22. Id. at 15 .

23. $I d$.

24. Id.

25. Id. at 19-20 (endnote omitted). 
to join the Kyoto Protocol to reduce carbon emissions by multinational treaty is a faulty presupposition: that causation of, and responsibility for, discrete incidents of flooding, tropical diseases, crop destruction, and the like are clearly and directly related to American carbon emissions which exceed its per capita "fair share" of sustainable carbon emissions. ${ }^{26}$ But what of the comparative fault of vulnerable nation-states to take prudent measures to adjust to gradual increases in global temperatures by such measures as encouraging certain crop substitutions, guiding development away from coastal areas, and launching preventative health measures such as vaccinations and public health improvements? What of the net benefits that so-called climate-damaged nations receive from services provided by developed nations with high per capita carbon emissionsservices such as foreign aid, direct foreign investment, innovative breakthroughs in life-saving and enhancing drugs, invention of pestresistant crops, and maintenance of international security and human rights?

Professor Singer is at his best in his book when he talks about emissions trading as a means to accomplish efficient global carbon reductions. ${ }^{27}$ Singer is right to commend the general efficiency of the emissions trading mechanism which "works," as he says, "on the same simple economic principle of trade in general: if you can buy something from someone else more cheaply than you can produce it yourself, you are better off buying it than making it." ${ }^{, 28}$ So far, so good. But Singer proceeds by jumping to the conclusion that the initial allocation of

26. See id. at 26-44 (discussing how to equitably distribute responsibility to reduce emissions) Professor Doug Kysar notes the following quibble with my critique of Singer:

I view Singer's book as making a series of arguments about which nations should bear the cost of such [environmental] adaptation measures - in other words, I view Singer as asking a question that is analytically prior to the assertion of comparative fault that you raise. How do we determine that low-lying Pacific island nations are comparatively negligent for failing to build levees, or [to] evacuate if we haven't resolved whether they are under a duty to mitigate damages in that fashion? Of course damages should be mitigated, but that's an efficiency point. The harder question is who should bear the costs, and that's a question of equity between nation-states and between generations of humans. We barely even have a language and a normative framework for debating those moral issues, let alone consensus agreement on specific rights and duties. Thus, to assert that developing nations are comparatively at fault requires a much more elaborate moral and political philosophical argument - precisely the kind of argumentation that Singer is offering, but with a much different conclusion.

E-mail from Douglas Kysar, Professor of Law, Cornell Law School, to Robert F. Blomquist, Professor of Law, Valparaiso University School of Law (Jan. 11, 2006, 18:23 CST) (on file with author).

27. See SINGER, supra note 4, at 46-49 (discussing the benefits of and objections to emissions trading).

28. Id. at 46 
greenhouse gas emissions should be based on "an equal per capita share." 29 This goes beyond economic efficiency and, without asserting as much, advocates a massive current redistribution of global wealth from the industrial developed nations, like the United States and the European Union, to rapidly developing countries with huge populations like India and China. Moreover, Singer's radical proposal would likely hinder economic growth in developed countries because of the considerable expense of industries in developed nations having to buy emission credits from developing countries. Singer's radical greenhouse emission trading proposal, then, is an example of what Bjørn Lomborg describes as a masked prescription to "fundamentally change the fabric of society" by failing to make explicit what the ulterior motive-beyond stabilization of global warming - happens to be. ${ }^{30}$

Singer buys into the Intergovernmental Panel on Climate Change (IPCC) and its call for "development, equity, sustainability, and sustainable development" along with climate policy. ${ }^{31}$ As Lomborg has convincingly demonstrated in his economic analysis of global warming:

[I]f we want to leave a planet with the most possibilities for our descendants, in both the developing and the developed world, it is imperative that we focus primarily on the economy and solving our problems in a global context rather than focusing - in the IPCC lingoon the environment in a regionalized context. Basically, this puts the spotlight on securing economic growth, especially in the third world, while ensuring a global economy, both tasks which the world has set itself within the framework of the World Trade Organization (WTO). If we succeed here, we could increase world income with \$107-274 trillion, whereas even if we achieve the absolutely most efficient global warming policies, we can increase wealth with just $\$ 0.245$ trillion .... To put it squarely, what matters to our and our children's future is not primarily decided within the IPCC framework [of global emission reductions and trading] but within the WTO framework. ${ }^{32}$

29. Id.

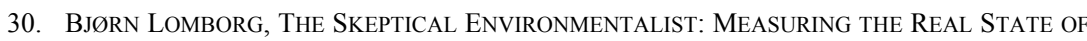
THE WORLD 321 (Hugh Matthews trans., Cambridge Univ. Press 2001) (1998). Lomborg has generated considerable controversy with this work. For various critiques and endorsements of Lomborg's book, see generally Symposium on Bjørn Lomborg's The Skeptical Environmentalist, 53 CASE W. RES. L. REV. 249 (2002).

31. LOMBORG, supra note 30 , at 320 (internal quotation omitted).

32. Id. at 324 (emphasis added). Lomborg also undercuts Singer's proposal for a national equal per capita emissions entitlement followed by trade of these emissions. According to Lomborg, the economically optimal benefit scenario for addressing global warming requires a global trading regime - with all nations able to trade - including "limits on the developing world emissions (if only at their business-as-usual level)," not, as Singer suggests, allowing high-population developing countries to have vastly increased allowances for greenhouse emissions. Id. at 311 . 
In a separate chapter of his book, One World, Professor Singer attacks the WTO on four grounds:

1. The WTO places economic considerations ahead of concerns for the environment, animal welfare, and even human rights.

2. The WTO erodes national sovereignty.

3. The WTO is undemocratic.

4. The WTO increases inequality; or (a stronger charge) it makes the rich richer and leaves the world's poorest people even worse off than they would otherwise have been. ${ }^{33}$

Singer's first ground of attack on the WTO is a claim that, in its jurisprudence, economics trumps all other values. In justifying this assertion, he questions the value of the WTO's process/product distinction ("a country cannot ban a product on the basis of the process by which the product was made but only by showing that the banned product is different in its inherent nature from other products"34), and also argues that General Agreement on Tariffs and Trade (GATT) Article $\mathrm{XX}$ is skewed by WTO arbitral rulings that undermine national laws to protect the environment by weighting the prohibition against "arbitrary or unjustifiable discrimination between countries" too heavily. Singer's process/product critique is bolstered by a penetrating recent Harvard Law Review article by Professor Douglas A. Kysar. ${ }^{36}$ Kysar persuasively argues that "many consumers have come to view themselves as purchasing with their disposable dollars not only products, but also shares of responsibility in the moral and ecological economy that produces them" 37 and that the process/product distinction "exist[s] uncomfortably within a global political climate that increasingly

Lomborg's essential economic analysis and critique of too abrupt a change toward lower emissions of greenhouse gases was born out of his Copenhagen Consensus project which asked eight of the world's leading economists to rank opportunities for solving the world's most vexing problems. See Global CRISES, GlobAl Solutions 605-07 (Bjørn Lomborg ed., 2004) (describing the project and giving the expert panel's ranking of the proposals). Singer-like proposals, according to the Copenhagen Consensus, yield too little global economic benefit at too much cost. See id. at 607 (noting that some members of the panel found a "proposal for non-reciprocal lowering of richcountry tariffs on exports from the least developed countries" would harm nonparticipating poor countries and would encourage participants to engage in activities that are not internationally competitive).

33. SINGER, supra note 4 , at 55.

34. Id. at 60 .

35. Id. at $66-70$.

36. Douglas A. Kysar, Preferences for Processes: The Process/Product Distinction and the Regulation of Consumer Choice, 118 HARV. L. REV. 525 (2004).

37. Id. at $640-41$. 
embraces market liberalism and the rhetoric of consumer choice as its fundamental guideposts." 38 Yet, while Singer is probably correct that the process/product distinction has become too heavy-handed and artificial, he is mistaken in attacking the nuanced and rational WTO jurisprudence interpreting GATT Article XX. It is vital for a well-functioning and efficient global economy that barriers to free trade be systematically reduced. As Professor Kym Anderson has demonstrated, "subsidies and trade barriers are not only economically wasteful but many also have harmful social and environmental effects" and "there are almost always cheaper ways of obtaining those social and environmental effects than via trade and subsidy measures." 39

Singer's second, third, and fourth attacks on the WTO are interrelated: the WTO erodes national sovereignty, ${ }^{40}$ is undemocratic, ${ }^{41}$ and exacerbates world poverty. ${ }^{42}$ The pragmatic response is yes, the consensual global tempering of national sovereignty (which is driven by special interest groups who influence politicians to pass protective, traderestrictive, rent-seeking national laws) is one of the key purposes of the WTO - a purpose that is beneficial to all the world's people through poverty alleviation and enhanced environmental quality. ${ }^{43}$ Nation-states are not forced to join the WTO. They choose to join (or seek to join) because of the fourfold national benefits they perceive as being part of a global trading community: (1) geopolitical stability, (2) efficient use of

38. Id. at 641 .

39. Kym Anderson, Subsidies and Trade Barriers, in Global Crises, Global Solutions, supra note 32 , at 541,569 .

40. SINGER, supra note 4 , at 70-75.

41. Id. at $75-77$.

42. Id. at $77-90$.

43. Significantly, while Singer concludes that his first three charges against the WTO are proven (by his own flawed interpretation of the evidence), "the fourth, and arguably most important charge against the WTO, . . that it makes the rich richer and the poor poorer, ... has . . . not [been] proven." Id. at 90-91. See also Anderson, supra note 39, at 562-63 (discussing how trade reform can help alleviate poverty). As Anderson explains in detail:

Much environmental damage in developing countries is a direct consequence of poverty (e.g. the slash-and-burn shifting agriculture of landless unemployed squatters). Insofar as trade reform reduces poverty, so it will reduce such damage. More generally, the relationships between per capita income and a wide range of environmental indicators have been studied extensively. Because richer people have a greater demand for a clean environment, income rises tend to be associated with better environmental outcomes once incomes rise above certain levels. Even though more pollutive products are being consumed as incomes rise, many abatement practices have been spreading fast enough to more than compensate. And openness to trade accelerates that spread of abatement ideas and technologies, making their implementation in developing countries affordable at ever-earlier stages of development.

$I d$. at 563 (second emphasis added) (footnote omitted). 
scarce resources, (3) wealth creation, and (4) dissemination of information and technology. ${ }^{44}$

Singer completes his diatribe against the WTO and globalization by raising some useful points that, while not carrying his argument, show the need for the global community to make further improvements in the social welfare of the people who live in the poorest countries on the planet. Unquestionably, we need to do a better collective job of raising individual life expectancies, increasing per capita incomes, alleviating hunger and undernourishment, and making globalization beneficial to all the world's inhabitants. ${ }^{45}$ Without a doubt, the rich member states of the WTO have to be less hypocritical and self-serving by more honestly and sincerely matching their rhetorical calls for greater free trade with their (often hidden) continuing protectionist measures (like imposition of much higher tariffs on manufactured goods from poor countries than on similar imports from rich countries and continued subsidization of domestic agricultural interests). ${ }^{46}$ Yet, Singer is unpersuasive when he leans hard to the left and suggests that a "global authority to set minimum standards on issues like child labor, worker safety, the right to form a union, and environmental and animal welfare protection" 47 is advisable. Singer, by contrast, is more convincing when he notes that the WTO's 2001 ministerial meeting at Doha might have signaled "a new concern for the interests of developing countries, including the world's poorest countries, and a willingness to consider other values as a constraint on what had hitherto been the overriding value of free trade. ${ }^{, 48}$

It would be more practical to utilize the existing structure of the WTO to bring about a step-by-step evolutionary incorporation of basic environmental and labor standards into the corpus of global trade rules than to establish warring, supranational single-issue agencies to issue edicts on these vital, but subsidiary, issues. ${ }^{49}$ Moreover, if the WTO

44. DAVID HunTER ET AL., INTERNATIONAL ENVIRONMENTAL LAW AND POLICY 1127-29 (2d. ed. 2002)

45. See SINGER, supra note 4, at 86-90 (considering various measures of well-being).

46. Id. at 95 .

47. Id. at 92; see also id. at 95 (stating that the WTO could promote "minimum standards for environmental protection, worker safety, union rights, and animal welfare").

48. Id. at 91. Singer qualifies this optimistic assessment with a more cynical one: "It will be several years before we know whether these [Doha] declarations were merely good public relations or a sign of a substantial change in the thinking of the WTO that will make a real difference." Id.

49. See, e.g., Robert F. Blomquist, Against Sustainable Development Grand Theory: A Plea for Pragmatism in Resolving Disputes Involving International Trade and the Environment, 29 VT. L. REV. 733, 742 (2005). As I stated previously:

Despite the surface attractiveness of grand sustainable development theories for centralizing international environmental governance into one global super-agency, for 
continues to moderate and soften its process/product distinction and to foster greater information to be freely disseminated concerning how products and services are produced, consumers in the global marketplace will become more adept in picking more environment- and labor-friendly commerce and bidding up the relative value of these trade items. ${ }^{50}$

\section{B. Public Citizen's Political Frontal Attack}

Public Citizen - a nonprofit citizen group founded by Ralph Nader in 1971 and based in Washington, D.C.--facilitated the 2004 publication of a book authored by Lori Wallach and Patrick Woodall entitled Whose Trade Organization?: A Comprehensive Guide to the WTO. ${ }^{51}$

The Public Citizen book is divided into twelve chapters (an introduction, ten numbered chapters, and a conclusion). The introduction, entitled "It's Not About Trade," contends that "the World Trade Organization - and the sprawling rules that it enforces - actually covers a huge array of subjects not included in past trade agreements that extend far beyond trade matters." 52 Upset with the emergence of more expansive and uniform international trading rules under the WTO, the book makes the misguided point that "[i]nstead of setting terms for international trade - exchange between different nations - these rules are

three reasons, it is naïve to expect that these centralizing/totalizing/top-down institutional schemes would lead to better coordination and coherence of international environmental standards, in general, or would result in better, more satisfactory resolution of trade versus environmental disputes. First, global environmental governance and sustainable development are problems that are primarily political and economic rather than structural. It seems highly doubtful that a global super-agency would be any more successful than the ad hoc progress that has been achieved (or any more adept at resolving future problems). Geopolitical "dog fights" are a realistic feature of international environmental and sustainable development disputes and will not go away by reconfiguring lines and boxes on an organization chart. Second, there is an inherent conflict between calls for a more powerful, centralized global environmental organization and increased citizen and nongovernmental organization (NGO) participation. Effective international sustainable development participation is probably more likely to occur in ad hoc settings and more workable on an issue-by-issue basis. Third, it seems likely that the creation of centralized global governing bodies with greater powers to craft international environmental law would hinder sustainable development, rather than promote it. Sustainable development . . . is primarily important as a contestable concept, and ultimately, agreement over the precise definition of the term is less important than the debate that is sparked by its brilliant ambiguity - a debate that can more fruitfully take place in numerous fora and varying contexts.

Id. at 742-43 (internal quotation marks and brackets omitted) (footnotes omitted).

50. See supra notes 34-39 and accompanying text (discussing the WTO's process/product distinction).

51. LORI Wallach \& Patrick WoOdall, Whose Trade Organization?: A COMPREHENSIVE GUIDE TO THE WTO (2004).

52. Id. at 1 . 
aimed at eliminating the diversity of national policies, priorities, and cultures to create the uniform world market sought by large multinational corporations." ${ }^{, 53}$ Yet, it is the various nation-states which seek a global trading arena with a uniform set of free-trade principles that are designed to pierce through nontariff trade restrictions disguised as national policies; while the "multinational corporations" have pressed for this rule set, it is the sovereign national governments of the world which have decided, in their collective wisdom, to adopt the rules. But, the book attributes the rise of the WTO to a massive conspiracy theory. ${ }^{54}$ The description of the protests in the streets of Seattle in December 1999 sounds like a dispatch from a socialist revolution, wherein it is claimed that anti-WTO activists (a "truly immovable mass of grassroots democracy") were responsible for blocking "[t]he allegedly unstoppable

53. Id.

54. Id. at 3-5. According to the Public Citizen book, the international agreement which establishes the "WTO and the 18 major agreements setting rules to which every signatory nation must conform their domestic policies" is characterized by the following eight themes:

- $\quad$ privatize and commodify all elements of the economy and society by pushing countries to treat everything from bulk water and public services to genetic materials and food as commodities to be made accessible as new for-profit tradeable units;

- deregulate by constraining the role of all levels of government and designating some domestic environmental, food safety and other regulations as trade barriers that must be eliminated;

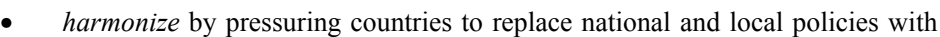
uniform global standards that are presumed to be WTO compliant while national standards providing a greater level of consumer protection in pesticide and meat inspection standards, environmental policies, accounting rules and more are exposed to WTO challenge;

- "liberalize" investment by requiring governments to eliminate policies regulating who can own what, including essential services, and to eliminate conditions on investors, such as requiring certain labor standards or environmental protections;

- "liberalize" finance by requiring countries to eliminate policies regulating banks, currency trading, derivatives, and stock markets;

- manage trade according to WTO rules. In contrast to "free trade," this is a "corporate-managed trade" system because of the special protections it provides for certain interests. For instance the WTO protects subsidies given to agribusiness to export commodities (thus allowing them to be dumped on markets at prices below the cost of production) while certain domestic subsidies to support small farms are characterized as illegal trade distortions;

- create new property protections, for instance requiring nations to adopt twenty-year monopoly patents on a wide array of items and giving foreign investors special rights not enjoyed by local businesses or citizens; and

- homogenize culture and consumer demands by treating culture as another commodity and eliminating government policies aimed at maintaining diverse media content.

Id. at $4-5$. 
force of corporate-led globalization" and subjecting this "force" to "democratic accountability" and restraint. ${ }^{55}$

Chapter 1 of the book focuses on the "WTO's [e]nvironmental [i]mpact." ${ }^{, 56}$ On the one hand, the least persuasive segments of this chapter are heavy on trade-bashing rhetoric. Examples along this line include the two following items. Item 1: "Environmentalists [concerned about the WTO before it came into existence in 1995] feared that the WTO's expansive new enforcement powers, combined with the antienvironmental bias in the substantive rules, would produce dire consequences for global environmental protection." the growing record of damaging evidence, neither the WTO Secretariat nor most WTO members . . . view the WTO as causing environmental problems. Although as the threats of WTO action against green policies escalate, it appears some view environmental policies as causing trade problems." $" 58$

Conversely, the most convincing portions of this Public Citizen chapter are fact-specific and nuanced. Worthy Example 1: The WTO has created counterproductive "[i]ncentives for [r]ip-and-[s]hip [e]xploitation of [n]atural [r]esources" ${ }^{\prime 59}$ because

[t]he Uruguay Round tariff schedules promote unsustainable rip-andship exploitation of forests, fisheries and minerals. The tariff escalation built into these schedules creates an incentive to ship unfinished materials. For example, rough tropical timber comes into the U.S. duty free, but plywood veneered with tropical wood has a tariff of $8 \%$, and almost all furniture above a limiting quota receives a $40 \%$ tariff. $^{60}$

Worthy Example 2: The WTO and other international institutions have fostered the destruction of forests:

55. Id. at 7 .

56. Id. at 19-50. Most of the remaining substantive chapters of the book, two through eight and ten, address issues beyond the scope of trade and the environment - such as the WTO's impact on food safety issues, on public health, on trade in services, on developing nations' economies, on agriculture, on human and labor rights, and the parallels between the WTO and the proposed Free Trade Area for the Americas (FTAA). Id. at 51-238, 262-81. However, Chapter 9 (addressing the WTO's operating procedures and enforcement system) is related to trade and environment issues, $i d$. at 239-61, and will, therefore, be discussed later in my critique. See infra notes 62-73 and accompanying text.

57. WALLACH \& WOODALL, supra note 51, at 19.

58. Id. at 50 .

59. Id. at 21 .

60. Id. 
The elimination of global commodity trade agreements (which used to set volume and price terms), as well as Uruguay Round tariff and quota cuts for many agricultural commodities such as coffee and cocoa, has increased the clearance of forests. Uruguay Round agriculture policy changes also have resulted in plummeting commodity prices, meaning that farmers have to produce more to make the same amount of money, pushing them to slash and burn more forests to expand their acreage. Meanwhile, in the face of falling commodity prices and continued pressure by the IMF and World Bank to pay back debts in hard currencies earned by exports, governments of developing countries are under pressure not to halt such forest destruction and indeed to intensify production of raw natural resources and cash crops that generate export earnings. ${ }^{61}$

One can conclude, from reflecting on the above observations concerning Public Citizen's Chapter 1 discussion, that the best way to approach trade and environment issues is to withhold broad-sweeping generalizations, avoid imputation of bad motives, and concentrate on concrete facts rather than abstract theoretical musings.

Public Citizen's Chapter 9 is proactively entitled "The WTO's Operating Procedures and Enforcement System: World Government by Slow-Motion Coup D'État", ${ }^{62}$ its target is the WTO's Dispute Resolution Understanding that "replaced the GATT . . . and its dispute resolution system, which relied more on diplomatic negotiation over disputes and which required consensus by all GATT countries for GATT dispute tribunal rulings to be adopted." ${ }^{\text {"3 }}$ Public Citizen objects to the power of WTO panel rulings, which are "unique among all other international agreements in that consensus is required to stop action." ${ }^{64}$ Moreover, Public Citizen is also concerned with the official U.S. government position that WTO-determined trade "sanctions or negotiated compensation are only interim measures and that WTO rules require countries to amend their domestic laws to comply with WTO rulings." 65 In addition, Public Citizen contends that the WTO "enforcement system is not designed to be a neutral arbitrator of disagreement between countries" since "WTO's stated purpose is expanding . . . trade in goods

\footnotetext{
61. Id. at 44 .

62. Id. at 239 .

63. Id.

64. Id. at 240 .

65. Id.
} 
and services and its enforcement system is designed to implement that purpose." ${ }^{66}$ In particular, Public Citizen is upset that

[m]any national policies that can run afoul of WTO's expansive rules are aimed at noneconomic goals, such as environmental or public health protection or labor-rights guarantees. While such policy making on the domestic level takes into account economic considerations, once such laws are subject to a WTO panel's review their validity is judged exclusively according to their conformity with WTO rules aimed only at maximizing trade and investment flows.

Thus, according to Public Citizen, "[t]he WTO's binding dispute resolution procedure and the Uruguay Round's expansive new rules encroaching into areas traditionally considered the realm of domestic policy effectively shift many decisions from democratically elected domestic bodies to secretive WTO tribunals." 68 Accordingly, "[t]his systematic shift of decision making away from accountable, open fora, such as parliaments and city councils is inherently troubling to those committed to the future of accountable, democratic governance in the era of globalization." 69

The Public Citizen critique uncovers one of the most difficult normative questions surrounding the WTO: Should expansion of international trade and the concomitant elimination of nontariff trade barriers with lowering of tariffs over time be a preeminent and trumping international legal principle, or should domestic health, food safety, labor, or environmental laws coupled with international environmental treaties be given equal or greater weight in trade disputes? In my view, in light of the broad, macroeconomic benefits that flow from free trade ${ }^{70}$ and the voluntary undertaking of individual nation-states to join the WTO, reasonable trade liberalization is an appropriate supreme legal standard to be pursued by WTO dispute panels. This is what I have called a "'blue' canon of interpretation (inspired by the open blue, borderless planet floating in space-[construing trade treaties in juxtaposition with competing national laws] in favor of as much

66. Id. (internal quotation marks omitted).

67. Id.

68. Id.

69. Id. "However, its implications are made worse by the abysmal lack of basic due process protection built into the powerful WTO dispute-resolution system. Although there has been ample criticism of the WTO's dispute-resolution mechanism and outcomes, little has been done to address the many demonstrated failures of the system." Id. at 240-41.

70. See supra note 44 and accompanying text (discussing perceived benefits of being part of a global trading community). 
liberalized and free trade as is reasonably feasible)." ${ }^{, 71}$ Yet, because of the vital importance of environmentally protective laws (whether domestic or international), I have also advocated a "green" canon of interpretation - which would urge WTO panel members to construe competing environmental laws as allowing as much environmental protection as is reasonably feasible. ${ }^{72}$ And, Public Citizen is right to insist on reasonable procedural improvements in the function of WTO dispute panels. Indeed, the WTO should be reformed in the following ways suggested by Public Citizen: (1) broaden the expertise of WTO tribunalists beyond those with expertise in merely international commerce to include arbitrators with expertise in environmental, health, and safety policy; (2) provide for required consultation of WTO arbitrators with environmental experts or experts in general international law when these matters are requested by a party to a dispute; (3) tighten conflict of interest standards for WTO arbitrators; (4) open up WTO cases to third-party amicus briefs; and (5) consider the creation of a prestigious court of last resort from the WTO's Appellate Body or the referral of final appeals to the World Court by way of discretionary review. ${ }^{73}$

\section{Corey Lofdahl's Systems Critique}

In an incisive and penetrating 2002 book, Environmental Impacts of Globalization and Trade, ${ }^{74}$ Corey L. Lofdahl employs a systems dynamics model to make explicit the complex causal relationships between world trade and environmental degradation. ${ }^{75}$ Using lateral pressure theory, Lofdahl concludes that Gross National Product (GNP) increases in developed countries are linked to deforestation in poorer, developing countries. ${ }^{76}$

Inspired by Professor Edward O. Wilson's magisterial book, Consilience: The Unity of Knowledge,${ }^{77}$ Lofdahl contends that "while the

1. Blomquist, supra note 49 , at 753 .

72. Id.

73. See Wallach \& WoOdall, supra note 51, at 246-50 (discussing problems with and possible reformations to the WTO).

74. COREY L. LOFDAHL, ENVIRONMENTAL IMPACTS OF GLOBALIZATION AND TRADE (2002).

75. Id. at $127-54$.

76. Id.

77. Edward O. Wilson, Consilience: The Unity of KnOWledge (1998). Lofdahl quotes Wilson as follows:

The greatest enterprise of the human mind always has been and always will be the attempted linkage of the [natural] sciences and the [social] humanities. The ongoing fragmentation of knowledge and resulting chaos in philosophy are not reflections of the 
problems of global environmental degradation are essentially physical, their solution has to be political. To study this topic [of the environmental impacts of globalization and trade] one must understand both social and natural environments." study of the environmental impacts of globalization and trade, Lofdahl makes a number of trenchant overarching observations that are worthy of attention.

First, he defines the term "globalization" as "increased linkages across national boundaries, expansion of the international market economy, and a complex and integrated world society." "79 Globalization entails trade, "Foreign Direct Investment (FDI), Multi-National Corporations (MNCs), advanced communication technologies, and migration" of humans. ${ }^{80}$

Second, Lofdahl summarizes the literature in favor of globalization. In this regard, he gathers from business books that "adaptation, competition, and survival" by persons and firms are essential in order to benefit from globalization and that excellence in "corporate culture, human resources, strategies, operations, structure, and organizational learning of best practices" by exemplary companies like General Electric, Whirlpool, Colgate-Palmolive, Shell, Coca-Cola, Xerox, Federal Express, and Hewlett-Packard is indispensable. ${ }^{81}$ Moreover, Lofdahl favorably notes business theorists who argue "that companies must serve customers, not governments; wealth comes from markets, not natural resources; and national borders are irrelevant." 82 Lofdahl draws upon economists in support of globalization, too; they claim "that Americans have historically benefited from globalization as trade delivered cheaper and better foreign goods, fostered improved international relations through the export of democracy, and even helped the United States win the Cold War." ${ }^{83}$ Lofdahl rounds out his summary of the benefits of globalization by casting the matter as a philosophical question "that centers on whether individuals choose their lifestyles for themselves or whether society determines lifestyles for the individual." ${ }^{, 84}$

real world but artifacts of scholarship. The propositions of the original Enlightenment are increasingly favored by objective evidence, especially from the natural sciences.

LOFDAHL, supra note 74, at xviii (alteration in original) (quoting WILSON, supra, at 8).

78. LOFDAHL, supra note 74 , at xviii.

79. Id. at 5 .

80. Id.

81. See id. at 6 (describing "a recipe for global success").

82. Id.

83. Id.

84. Id. at 7 . 
"The answer, according to . . globalization's proponents, is a resounding yes for individual choice" where "[g]lobalization is not so much the result of American power as the natural and progressive development of international relations, cultural institutions, and the rise of individualism." 85

Third, Lofdahl recaps the downsides of globalization. In this regard, he gathers "progressive international economic scholarship . . . that highlights the unintended consequences and costs of globalization from the point of view of poor, developing countries." "emerging, global forms of production, exchange, and governance from the perspective of Sub-Saharan Africa, the Middle East, East Asia, and Latin America," Lofdahl cites economic studies that show "that the poor in these regions experience significant unmet needs including hunger, housing, unemployment, poverty, human rights, and the degradation of their natural environment." ${ }^{, 87} \mathrm{He}$ goes on to provide a synopsis of economic critiques of MNCs as "powerful international actors that further globalization and cause many of its significant negative consequences." 88 MNCs range across national frontiers and "are unbounded by national loyalties and are free to pursue short-term economic gain, which often comes at the expense of the natural environment." 89 Lofdahl cites studies that claim "that globalization is a socially destabilizing force, both at the personal and national levels" and contend that "[d]eveloped countries protect their domestic environments by moving production to developing countries where environmental standards are looser, which effectively exports pollution." 91

Lofdahl's principal contribution to understanding trade and the environment is his development of a quantitative simulation model that "demonstrates just how the North pushes its environmental costs to the South." ${ }^{92}$ Specifically, Lofdahl's model is what he calls an Environmental Lateral Pressure model that turns on "three master variables of lateral pressure: population, technology, and resources." 93 The statistical results generated by analysis of Trade Connected GNP 
between the rich countries of the North and the poor countries of the South demonstrate

\begin{abstract}
that trade provides the mechanism by which the costs of industrialization are pushed off by rich countries onto poor ones. . . . These terms of trade deliver asymmetric benefits: economic development and a clean environment for the North; economic stagnation and environmental degradation for the South. . . . If one works for a rich, northern $\mathrm{MNC}$ and is reaping the rewards of globalization, then one will tend to support trade. If one is instead an unemployed citizen of a poor, southern country, then one is more likely to be suspicious of globalization's benefits. That wealth drives environmental externalization also makes sense from a micro perspective: if the citizens of a rich, northern country desire a product with prohibitive environmental costs - say, cheap wood furniture - then if given the opportunity, they will import the product from a developing country rather than pay higher prices, or they will do without. Such decisions are made almost automatically by the market's, "invisible hand," made all the more invisible by the modern, international economy. Developing countries, in some sense, are forced by their poverty into responding to such forces and selling their natural resources $_{9_{4}}$ thereby placing them into the also-ran role of commodity provider. $^{94}$
\end{abstract}

Corey Lofdahl suggests a pragmatic way to think about trade and the environment by offering what Professor Sanford E. Gaines calls a "sociopolitical critique of trade policy" that constitutes "a fresh and disquieting analysis of deeper environmental and economic consequences of current patterns of world trade." ${ }^{95}$ As Gaines argues, if Lofdahl is right, "the strategy of externalizing significant environmental costs has worked for developed countries because they have had developing countries available to provide the resources they need and absorb the displaced environmental harms associated with their extraction." "96 Indeed, "[t]he global effort to achieve sustainable development, though, has the goal of raising GNP levels in developing countries, and the trade-environment relationship must be judged on the capacity of trade to promote sustainable development broadly." 97 Lofdahl's lateral pressure theory analysis uncovers the fundamental trade-environment problem: "the possibility that developing countries will be unable to replicate the development trajectory of the developed

94. Id. at 157

95. Sanford E. Gaines, The Problem of Enforcing Environmental Norms in the WTO and What to Do About It, 26 HaSTINGS INT'L \& COMP. L. REV. 321, 338 (2003).

96. Id. at 339 .

97. Id. 
countries because they have no place to externalize the environmental costs associated with their own increased consumption of resources as they try to develop their economies."

While there are some minor flaws with Lofdahl's analysis, ${ }^{99}$ it is attractive for its influence on policy makers and its popular resonance, ${ }^{100}$ as well as its "dovetail[ing] with the environmental questioning of the fundamental legitimacy of trade policy in an ecologically-limited world." 101 Moreover, Lofdahl's insights fit with the analysis of Thomas Princen, who has emphasized the problem of exportability involving "the increasing ease of exporting the risks of critical threats and escaping responsibility for their creation" in the international trading system. ${ }^{102}$

\section{ENVIRONMENTAL OPTIMISTS OF GLOBALIZATION}

\section{A. Jagdish Bhagwati's Plea to Cope with and Improve Globalization}

In his sweeping and ambitious book, In Defense of Globalization, ${ }^{103}$ Professor Jagdish Bhagwati claims that "[g]lobalization has a human face, but we can make that face ... more agreeable." 104 Bhagwati makes his case for fixing - not scrapping - globalization in five parts. $\mathrm{He}$ focuses Part I on "understanding the anti-globalization movement and defining its concerns, while analyzing the growth of non-governmental organizations that play a principal role in the anti-globalization phenomenon and can play an important role in the design of appropriate

98. Id. "In other words, international trade may have been 'mutually supportive' of environmental protection from the perspective of the developed economies, but it may not be able to operate in the same mutually supportive fashion for the developing countries." Id.

99. As Gaines has pointed out: "Among the methodological questions that arise is whether forest cover [in Lofdahl's model] is a suitable proxy for relationships in trade of natural resources. Substantial proportions of tropical deforestation and temperate region afforestation are attributable to demographic pressures and changing agricultural practices within countries, not to trade in forest products." Id. n.57.

100. Id. at 339 .

101. Id. at 339-40 (citing Herman E. DALY \& JOHN R. COBB, JR., FOR THE COMMON GOOD: REDiRECTING THE ECONOMY TOWARD COMMUNITY, THE ENVIRONMENT, AND A Sustainable FutURE 143-44 (1994); Douglas A. Kysar, Law, Environment, and Vision, 97 Nw. U. L. REV. 675 (2003); Douglas A. Kysar, Sustainability, Distribution, and the Macroeconomic Analysis of Law, 43 B.C. L. REV. 1 (2001)).

102. Id. at 341 (quoting Thomas Princen, Principles for Sustainability: From Cooperation and Efficiency to Sufficiency, 3 GloBAL ENVTL. POL. 33, 40 (2003)). For Professor Gaines's most recent insights on this topic, see CHRIS Wold, SANFORD GAINES \& GREG BLOCK, TRADE AND THE ENVIRONMENT (2005).

103. JAGDish BhagWATI, In DEFENSE OF GLOBALIZATION (2004).

104. Id. at $\mathrm{x}$. 
governance to improve outcomes from globalization."105 In Part II,
Bhagwati tackles several discrete potential problems raised by
international trade via MNCs including: (1) Poverty: Enhanced or
Diminished? ${ }^{106}$ (2) Child Labor: Increased or Reduced?; ${ }^{107}$ (3) Women:

105. Id. Bhagwati makes a number of well thought-out points in this Part. First, he defines globalization broadly as "economic globalization." Id. at 3. "Economic globalization constitutes integration of national economies into the international economy through trade, direct foreign investment (by corporations and multinationals), short-term capital flows, international flows of workers and humanity generally, and flows of technology ...."Id. Second, antiglobalization is the product of a number of influences: from anticapitalist ideologues, to anticorporation attitudes, to the philosophical views of communitarianism, to anti-Americanism. Id. at 21-27. Third, he asserts that it is appropriate to "believe that globalization has a human face" that should be ameliorated by "policies to enhance, supplement, complement, and accentuate its good outcomes." Id. at 31 . Fourth, he contends that three principal prescriptions should be followed in "making the beneficial globalization process work even better." Id . at 32. These three prescriptions are as follows:

The beneficial outcomes are only what economists call a "central tendency," which is to say that they hold for the most part but not always. They leave room for downsides, and we must have institutional mechanisms to cope with such adverse outcomes if and when they materialize.

Also, we will want to go faster in achieving social agendas than globalization permits and facilitates. The question then is: what choice of policy and institutions will achieve that acceleration?

Finally, we can never forget also that a transition to more rewarding globalization requires careful steering and optimal speed of policy changes, not maximal speed à la the Id. "shock therapy" of excessively rapid reforms that devastated Russia.

106. Id. at 51 (quotation marks omitted). Bhagwati's discussion of potential environmental perils, id. at 135-61, is assessed in detail later in this Article. See infra notes 119-39 and accompanying text. Bhagwati's discussion of poverty aspects of globalization, BHAGWATI, supra note 103, at 51-67, makes a number of salient observations. First, for trade to enhance a nation's growth and thereby reduce poverty, growth should not be "a passive, trickle-down strategy for helping the poor," but rather should be "an active, pull-up strategy instead." Id. at 54. Second, developing economies need to diversify into production of multiple labor-intensive industries in order to avoid depressed terms of trade coming about from overproduction (leading to price decrease) of one commodity-like Bangladesh's unhappy experience with jute production in the 1950s. Id. at 54-55. Third, developing economies should eschew import substitution strategies since such misguided approaches undermine "the cause of the poor by reducing growth and by delinking it from increased [foreign] demand for the low-grade labor that constitutes the bulk of the poor." Id. at 56-57. Fourth, to allow the poor in developing countries to gain optimal access to capital, bureaucrats should be replaced as much as possible by markets since "far too many bureaucrats impose senseless restrictions just to collect bribes or to exercise power." $I d$. at 58 . Fifth, political democracy and such legal innovations as allowing NGOs to have standing on behalf of the poor are "a powerful tool for aiding the poor." Id. at 58-59. Sixth, other virtuous social policies-such as "high literacy, and emphasis on higher education"- need to work in tandem with wise economic policies to assist the poor. Id. at 63 .

107. Id. at 68 (quotation marks omitted). Bhagwati articulates several penetrating observations about globalization and child labor. First, "globalization-wherever it translates into greater general prosperity and reduced poverty — only accelerates the reduction of child labor and enhances primary school enrollment and hence literacy." Id. Parents in poor developing countries, when able to earn a moderate amount of additional income through the benefits of freer trade, tend, pursuant to what economists label the "income effect," to invest in greater education of their children. Id. at 69-70. Third, recent econometric data examining Vietnamese households confirm the operation of the income effect of parents investing in greater education for their children when enjoying greater 


\section{Harmed or Helped?; ${ }^{108}$ (4) Democracy at Bay?; ${ }^{109}$ (5) Culture Imperiled or Enriched?; ${ }^{110}(6)$ Wages and Labor Standards at Stake?; ${ }^{111}$ and (7)}

income from rice exports grown by their parents. Id. at 71. A "caveat" is in order, however, regarding the following problem:

The increased demand for labor in some of the labor-scarce Middle Eastern nations without modern protections and rights, especially Saudi Arabia, has led to the crossborder movements of women and their children, employed as domestic labor, often in poor conditions. Child prostitution has also intensified, with female children being transported across borders and sold into brothels. These are products of globalization only in the sense that there are profits to be had in movements across borders. And all are agreed that these developments call for corrective action.

Id. at 72 .

108. Id. at 73 (quotation marks omitted). Bhagwati explains "[t]hat globalization can help rather than harm women" as illustrated by "how globalization has affected the women of Japan." Id. at 74. This positive impact on Japanese women was due to their exposure to Western culture when they moved with their husband-executives of multinational corporations to the United States and other Western nations and from an increase in Japanese women studying at Western universities. Id. at 74-75. Moreover, he contends that gender discrimination is costly and that globalization tends to put competitive pressure on firms to stop this type of discrimination. Id. at 76 . Yet, Bhagwati, by acknowledging "three critical phenomena, tangentially related to globalization, that pose unambiguous threats to women's well-being," id. at 89 , demonstrates his evenhanded credibility and honesty in evaluating the good and the bad of globalization. These three threats to women's welfare are:

- Women going abroad as domestic servants — often to the Middle East, where local women are typically living in the Middle Ages ... have been subjected to abuse and need protection.

- The growth of tourism has inevitably been accompanied by a rise in female and even male prostitution in countries such as Thailand.

- Trafficking in women has grown, especially with the economic distress that has attended attempts at transition in countries such as Russia and from financial crises in afflicted Asian countries.

Id. at 89 .

109. Id. at 92 (quotation marks omitted). Professor Bhagwati offers us a paradox on the issue of globalization and democracy: "globalization promotes democracy while constraining it at the same time." Id. at 93 . On the one hand, he notes that "[g]lobalization promotes democracy both directly and indirectly." Id. This is the case, according to Bhagwati, because:

The direct link comes from the fact that rural farmers are now able to bypass the dominant classes and castes by taking their produce directly to the market thanks to modern information technology, thereby loosening the control of these traditionally hegemonic groups. In turn, this can start them on the way to becoming more-independent actors, with democratic aspirations, in the political arena.

$I d$. On the other hand, Bhagwati admits that, given the centralized structure of trade organizations such as the WTO, a full panoply of democratic procedures available at the domestic level in some countries may not be available. Id. at 104-05.

110. Id. at 106 (quotation marks omitted). In a far-ranging discussion on globalization and culture, Bhagwati concludes that "[w]here Americans see technology as solving problems, others see it as creating them." Id. at 121 . "That difference . . for sure, underlies the contrasting positions taken by Americans and the Europeans on the issues of hormone-fed beef and genetically modified (GM) products." Id. Thus, "Americans uniquely find it difficult to see why free trade in cinema, television, GM products, and so on is considered by others to pose a threat to their culture and wellbeing." Id.

111. Id. at 122 (quotation marks omitted). Bhagwati claims that available economic evidence shows that globalization has created a paradoxical "race to the top" in global wages and labor 
Corporations: Predatory or Beneficial? ${ }^{112}$ Moreover, a separate chapter in this Part focuses on the environmental impacts of globalization, ${ }^{113}$ which is discussed at length below. ${ }^{114}$ In Part III of his book, Bhagwati addresses "other facets of economic globalization: short-term capital flows and the movements of people across borders."115 In Part IV, he "consider[s] the design of institutional changes, both domestic and international, that are necessary to make the generally good effects of globalization even better." "Interestingly, Bhagwati parts company, in this Part, with "the anti-globalization critics: the appropriate governance - that is, institutions and politics - that goes with a globalization that is seen as having a human face is very different from that which attends a globalization that is seen as lacking a human face."117 Finally, in Part V, he concludes with a few pithy parting thoughts, the essence of which can be summarized as follows: "[r]eason and analysis require that we abandon the conviction that globalization lacks a human face, an assertion that is tantamount to a false alarm, and embrace the view that it has one." 118

standards due to political and economic reasons. Id. at 127-32.

112. Id. at 162 (quotation marks omitted). Bhagwati argues that "the evidence strongly suggests" that multinational corporations have been a beneficial force. $I d$. at 163 . He explains that the chief beneficial impact from multinational corporations has been positive "spillovers":

These refer to the fact that domestic firms learn productivity-enhancing techniques from multinationals with better technology and management practices. We can identify channels through which such diffusion may occur. Managers may learn by observing or hearing about better management practices or by the experience of having previously worked at multinationals. Such diffusion may also happen with production workers, who learn better discipline, for example, when employed by the foreign firms and then take it with them to local firms, where their experience is translated into a better workforce. Id. at $180-81$.

113. Id. at $135-61$.

114. See infra notes 119-39 and accompanying text.

115. BHAGWATI, supra note 103, at $\mathrm{x}$. As he explains:

Short-term capital flows, which broadly consist of transactions in stocks and related financial instruments for short-term gains as distinct from direct equity investment by enterprises for long-term gains, and human movements across borders (legal and illegal, voluntary or forced by crisis and circumstance) are in fact two principal forms of economic globalization that raise a number of difficult questions . . . deserv[ing] attention in a book that is addressed to globalization on a broader scale than just trade and direct foreign investment.

Id.

116. Id.

117. Id. Bhagwati discusses appropriate governance, coping with downsides, accelerating the achievement of social agendas, and managing transitions through optimal, not maximal speed in Part IV. Id. at 219-62.

118. Id. at 265. 
Professor Bhagwati asks whether the environment is in peril by the continued emergence of free-trade globalization. ${ }^{119}$ He warms up to the subject by observing that "conflict is inevitable" because "[i]mpassioned differences often arise from the altogether different philosophies and lifestyles of trade economists and environmental activists." ${ }^{20}$ In particular, according to Bhagwati, "[t]he environmentalists . . . tend to value environment over income, whereas trade (and other) economists conventionally tend to value income over the environment."121 From these foundational assumptions, Bhagwati highlights a "[c]ommon [f]allacy," held by some environmentalists, "that if trade is freed without environmental policies being in place, not only will the environment be harmed but the country's economic welfare will be set back."122 Admitting "[t]hat this may happen is surely correct," ${ }^{23}$ he claims "[t]hat it must happen is incorrect." ${ }^{\text {"124 }}$ Citing various empirical data, Bhagwati asserts:

I and my GATT colleagues Richard Blackhurst and Kym Anderson addressed this issue in 1991 when I was economic policy adviser to [the director general of GATT]. The GATT Secretariat was working on a special report on trade and the environment, and we took the occasion to clarify matters. In particular, we provided examples from the real world that showed that, contrary to the environmentalists' pessimistic certainties, economic welfare increased with trade liberalization even though ideal environmental policies were not in place, and that the environment improved also.

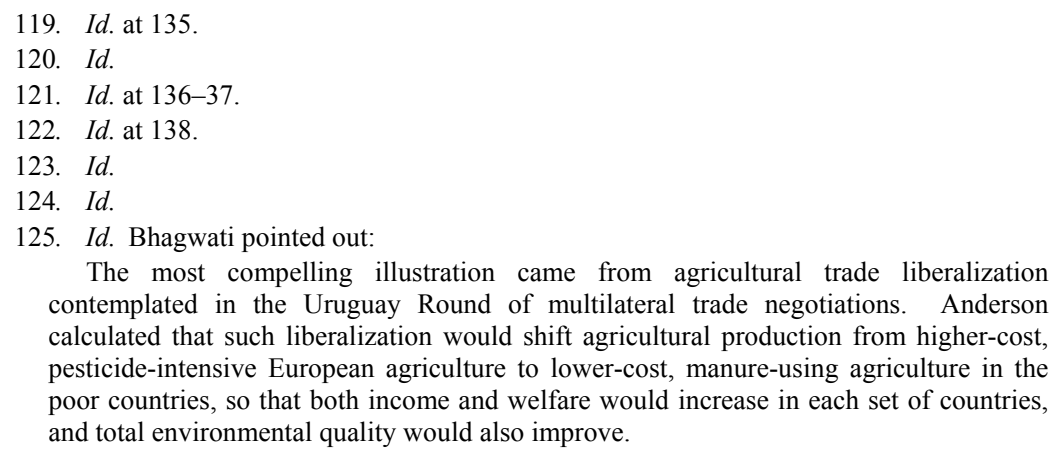
pesticide-intensive European agriculture to lower-cost, manure-using agriculture in the poor countries, so that both income and welfare would increase in each set of countries, and total environmental quality would also improve.

Id. Bhagwati, however, acknowledges that there have been negative examples where free trade, "in the absence of an appropriate environmental policy" that makes producers pay for the pollution they cause, can lead to "harmful environmental spillovers." Id. at 139-40. A classic example of harmful environmental spillovers is "the rapid expansion of coastal shrimp farming in the 1980s in several countries in Asia and Latin America, principally in Ecuador, Colombia, Indonesia, Thailand, the Philippines, India, Bangladesh, China, Taiwan, and Vietnam." Id. Three serious environmental problems from the expansion in trade of coastal shrimp-farming were: 
As Professor Bhagwati sees it, "the optimal policy is to have an appropriate environmental policy in place, to look after the environment, and then to pursue free trade to reap the gains from trade." ${ }^{, 26}$ He uses the conditional word "appropriate," "[b]ecause, except in the limiting cases where you want to put an infinite value on an environmental outcome, you are going to have to balance income gains against environmental benefit." 27 This insight is pragmatic and realistic-realizing that nothing occurs in the real world without some balancing of costs and benefits. Focusing on the example of coastal shrimp harvesting and international trade from countries in Asia and Latin America, Bhagwati opines:

In the coastal shrimp case it is hardly sensible to say that the environmental considerations should be so overwhelming that no environmental damage to mangrove forests should be accepted. Rather, such damage must be balanced against the loss from shrimp export earnings. This trade-off will imply a choice somewhere between a zero pollution tax and a prohibitive one, of course. This choice will obviously reflect the societal valuation of the environment and income . $\ldots^{128}$

Thus, for Bhagwati, the "[r]eal [q]uestion" boils down to "[h]ow to value the environment," a matter that he urges "needs more scrutiny." 129 On the one hand, he agrees with the proposition argued by environmentalists "that growth rates must be adjusted for environmental damage" since "[g]rowth that devastates the environment is surely not being correctly measured if no downside adjustment for the environmental damage is made." 130 On the other hand, Bhagwati argues that "environmentalists are more credible [and more pragmatic] if they ask, quite properly, for a rise in the relative valuation of environment to income," 131 instead of making a claim "which puts zero weight on

- The shrimp ponds produced effluents that contaminated the water supply for others (and for themselves as well).

- They used large quantities of fresh water, which then led to a drop in the water table and the intrusion of salt water.

- Their expansion often led to the destruction of surrounding mangrove forests, with serious consequences for commercially valuable fish and shrimp stocks which depend on a mangrove habitat ....

$I d$. at 140 (endnotes omitted) (internal quotation marks omitted).

126. Id. at 141

127. Id.

128. Id.

129. Id

130. Id.

131. Id. at 142 . 
income and infinite weight on environment [preservation]." Such claims are exemplified by inflated environmentalist rhetoric attacking some deforestation in the boreal Canadian forests from American "demand for softwood, pulp, and paper in the United States" and some deforestation in the Brazilian Amazon for "mahogany and other precious hardwoods." 132 A pragmatic approach to trade and the environment problems, therefore, is characterized by a taste for "systematic and comprehensive analysis" "133 that appreciates complexity and understands that proposed solutions have second-order and feedback consequences. ${ }^{134}$

When Professor Bhagwati turns his attention to the policies and decisions of the WTO - the preeminent arbiter of trade and environmental disputes - he offers several pragmatically insightful comments. In the first place, he suggests that on "safety in agricultural trade"135 issues, like hormone-fed beef and genetically modified product disputes, a more flexible and useful approach by the WTO Appellate Body would be to encourage "eco-labeling" of agricultural products so that consumers around the world can decide for themselves-based on accurate and pertinent information - what kind of food to consume. ${ }^{136}$ In the second place, regarding "values-related decisions affecting production and process methods (PPMs) that violate ethical preferences," ${ }^{137}$ like tuna fishing methods that harm dolphins or shrimp harvesting techniques that injure turtles, Bhagwati counsels prudence and wisdom. ${ }^{138}$ Specifically, he makes the common sense recommendation that instead of pursuing ineffective trade sanctions against developing nations' fishermen, who lack the sophisticated and costly technology to selectively harvest fish without harming favored marine creatures, "the rich and powerful countries that wish to propagate their moral preferences . . . should proceed to subsidize the PPMs that they advocate (e.g., non-use of purse seine nets and use of TEDs [turtle exclusion devices]), putting their own resources where they claim their moral preferences are." 139

\footnotetext{
132. Id. at $141-42$.

133. Id. at 143 .

134. Id.; cf. Robert F. Blomquist, The Beauty of Complexity, 39 HaSTINGS L.J. 555, 570-71 (1988) (reviewing William H. Rodger, JR., ENVIRONMENTAL LAW: Air and WATER (1986)) (considering the beauty of environmental law's complexity).

135. BHAGWATI, supra note 103 , at 151 .

136. Id. at $152-53$.

137. Id. at 153 .

138. See id. at 155-56 (stating that an "open-ended automatic legitimation of values-related PPM-based exclusions is unwise").

139. Id. at 157-58. Indeed, subsidies are often a more efficient and effective way to legally order the environment compared to direct regulation and penalties. Bhagwati goes on to observe:
} 


\section{B. Jeffrey Frankel's Upbeat View on Three Ways That Globalization Can Be Good for the Environment}

In his sober yet buoyant contribution to the 2005 book Globalization: What's New, ${ }^{140}$ Professor Jeffrey A. Frankel-harking back to the street theatrics at the Ministerial Meeting of the WTO in Seattle during November 1999 when antiglobalization protestors demonstrated while wearing turtle costumes - starts off his chapter, "The Environment and Economic Globalization," with a stark observation. ${ }^{141}$ He writes: "Perhaps no aspect of globalization worries the critics more than its implications for the environment." "142 Frankel acknowledges that such concern is "understandable" and "the case for countries sticking their noses into each other's business is stronger" since "[w]e all share [the same] planet."143 In sparse and elegant prose he puts forth the central question of international trade and the environment as follows:

[Use of subsidies], in fact, [is] exactly what the signatories to the Kyoto treaty on global warming have done: recognizing that the developing countries have resource problems, because they are poor, the rich countries have promised resources, financial and technological, to enable them to make the switch to processes emitting less carbon into the atmosphere. In the same vein, the best solution to the shrimp-turtle problem would surely have been for the United States to buy the TEDs, which presumably cost about $\$ 50$ a net, and send them gratis to the developing countries for their use. I doubt if more than about $\$ 10$ million would have been involved; that is less than a tenth of the money that the IMF [International Monetary Fund] spends on travel every year.

Id. at 158. For a discussion of the policy tools for legally ordering the environment, see ROGER W. Findley ET AL., CASES AND MATERIals ON ENVIRONMENTAL LAW 62-63 (6th ed. 2003). For a previous discussion by Bhagwati on issues of free trade and the environment, see JAGDISH BHAGWATI, FREE TRADE TODAY 57-67 (2002), which discusses "fair trade arguments that relate to differences in (domestic-pollution-related) environmental and labor standards across countries" and arguments that "free trade harms the environment."

140. Jeffrey A. Frankel, The Environment and Economic Globalization, in GloBALIZATION: WHAT'S NEW 129-69 (Michael M. Weinstein ed., 2005).

141. Id. at 129 .

142. Id.

143. Id. Frankel restates the classic law and economics rationale for legal ordering of the environment:

Pollution and other forms of environmental degradation are the classic instance of what economists call an externality: the condition under which individuals and firms, and sometimes even individual countries, lack the incentive to restrain their pollution, because under a market system the costs are borne primarily by others. The phrase "tragedy of the commons" was originally coined in the context of a village's shared pasture land, which would inevitably be overgrazed if each farmer were allowed free and unrestricted use. It captures the idea that we will foul our shared air and water supplies and deplete our natural resources unless somehow we are individually faced with the costs of our actions.

Id. at $129-30$ 
[W]hether globalization helps or hurts in achieving the best tradeoff between environmental and economic goals. Do international trade and investment allow countries to achieve more economic growth for any given level of environmental quality? Or do they undermine environmental quality for any given rate of economic growth? Globalization is a complex trend, encompassing many forces and many effects. It would be surprising if all of them were always unfavorable to the environment, or all of them favorable. The highest priority should be to determine ways in which globalization can be successfully harnessed to protect the environment rather than to degrade it. ${ }^{144}$

Professor Frankel tells us, in piercing language, "that it is an illusion to think that environmental issues can be effectively addressed if each country were insulated against incursions into its national sovereignty at the hands of international trade or the WTO."145 Bursting this illusion with bracing common sense, he points out that "[i]ncreasingly, people living in one country want to protect the air, water, forests, and animals not just in their own countries, but also in other countries as well."146 To accomplish these worthy ends, in Frankel's view, "international cooperation is required" and "[n]ational sovereignty is the obstacle to such efforts, not the ally." 147 Indeed, "[m]ultilateral institutions are a potential ally, not the obstacle."148

With his eyes focused on the practical and the concrete, Professor Frankel articulates the argument, and previews for the reader, the gist of his chapter: there are "three ways in which globalization can be a means of environmental improvement." "149 The first way involves "the exercise of consumer power." " Essentially, the international consumer exercises choice by reading product or service labels that describe how a unit of potential consumption was or is produced and then the consumer decides whether the environmental factors of production justify her purchase. But, for environmental labeling to work, according to Frankel, "there need to be some rules or standards. Otherwise, any producer could inaccurately label its product as environmentally pure, and any country could unfairly put a pejorative label on imports from rival producers."151

\footnotetext{
144. Id. at 130

145. Id.

146. Id.

147. Id.

148. Id

149. Id

150. Id.

151. Id.
} 
Thus, the second way that globalization can help achieve global environmental improvement is through "a system in which countries interact under a set of multilateral rules determined in multilateral negotiations and monitored by multilateral institutions." 152 As Frankel sees it, "the WTO has actually moved importantly in the environmentalists' direction in recent years" by WTO arbitral panel decisions which suggest that, under some circumstances, nations "are to be allowed to adopt laws that may be trade-restricting, but that have as their objective influencing other countries' process and production methods (PPMs), such as their fishermen's use of nets." 153 The only limitation on this WTO trend in trade and environmental law "is that the [national PPM] measures cannot be unnecessarily unilateral or discriminatory. ${ }^{154}$ But, " $[\mathrm{t}]$ he environmentalist community," reacting in a decidedly unpragmatic manner, "has almost entirely failed to notice this major favorable development, because of confusion over" the WTO's qualification of national PPM laws. ${ }^{155}$ Offering sage advice, Frankel opines that the environmental community is behaving foolishly, since "[b]y ignoring their victory on the main issue - the legitimacy of addressing PPMs - environmentalists risk losing the opportunity to consolidate it." 156 Moreover, environmentalists should be wary of blowing it, given the political reality that "[s]ome players, particularly poor countries, would love to deny the [PPM] precedent set in these panel decisions, and to return to a system where other countries cannot restrict trade in pursuit of" legitimate concerns about the global commons. ${ }^{157}$ A wise and strategic approach for environmentalists would be to engage in debate on "how reasonably to balance both economic and environmental objectives" $" 158$ before the WTO and other potential multilateral tribunals.

Besides consumer power and multilateralism, there is a third reason to think that emerging twenty-first-century globalization can be beneficial to the environment: cross-country "statistical evidence on how globalization and growth tend to affect environmental objectives" that

152. Id.

153. Id. at 131 .

154. Id.

155. Id

156. Id.

157. Id.

158. Id. Reasonableness and the reasonably prudent person standard are concepts with which lawyers - particularly tort lawyers - are quite familiar. See Robert F. Blomquist, Re-Enchanting Torts, 56 S.C. L. REV. 481, 493 (2005) (describing the common law tort of negligence and its "law and economics utilitarian, risk-balancing calculus"). 
can help policymakers to discern whether global environmental externalities remain to be resolved. ${ }^{159}$ On the one hand, Frankel contends that this statistical evidence demonstrates that "[i]ncreased international trade turns out . . . beneficial for some environmental measures, such as $\mathrm{SO}_{2}$ pollution," with "little evidence to support the contrary fear that international competition in practice works to lower environmental standards overall." 160 Instead he argues that "globalization . . . aid[s] the process whereby economic growth enables people to demand higher environmental quality." 161 On the other hand, Frankel opines that "[f]or the increasingly important category of global environmental externalities, however, such as greenhouse gases," comparative statistical evidence demonstrates that "regulation at the national level is not enough," and therefore, "[a]n international agreement is necessary." concludes this part of his chapter with a bold synthesis:

These three new reasons to think that globalization can be beneficial for the environment - consumer power, multilateralism, and cross-country statistical evidence - are very different in nature. But in each case what is striking is how little the facts correspond to the suspicions of critics that turning back the clock on globalization would somehow allow them to achieve environmental goals. The rise in globalization, with the attempts at international environmental accord and quasi-judicial oversight, is less a threat to the environment than an ally. It is unfettered national sovereignty that poses the larger threat.

In the remainder of his essay on the relation between the environment and economic globalization, Professor Frankel covers five key conceptual points: (1) Objectives, (2) Regulation, (3) Effects of Openness to Trade, (4) Potential Conflicts Between Globalization and Environmental Regulation, and (5) International Agreements and Institutions. ${ }^{164}$

159. Frankel, supra note 140, at 131.

160. Id.

161. Id. He further elaborates:

To be sure, effective government regulation is probably required if this demand is ever [sic] be translated into actual improvement; the environment cannot take care of itself. But the statistical evidence says that high-income countries do indeed eventually tend to use some of their wealth to clean up the environment, on average ....

Id. at $131-32$

162. Id. at 132 .

163. Id. (emphasis added).

164. Id. at 132-59. 


\section{Objectives}

Professor Frankel lucidly explains that, from a public policy standpoint, "both economic income and environmental quality are worthy objectives." 165 True, he observes, "[i]ndividuals may disagree on the weight that should be placed on one objective or another." ${ }^{\text {"66 }}$ Yet, "we should not let such disagreements lead to deadlocked political outcomes in which the economy and the environment are both worse off than necessary." 167 Frankel explains numerous principles concerning public objectives. First he asserts that, contrary to "[a]n extreme version of environmental activism [that] argue[s] that we should turn back the clock on industrialization," 168 today "[m]ost people believe that both a clean environment and economic growth are desirable, that we can have a combination of both, and it is a matter of finding the best tradeoff." 169 In this regard, Frankel stresses the importance of precision in our conceptual thinking ("for example to make the distinction between effects on the environment that come via rapid economic growth and those that come for a given level of economic output"). ${ }^{170}$ Moreover, he laments the lack of a comprehensive and robust measure of environmental quality; this is in contrast to the "single concept, GDP, that attempts to measure the aggregate value of goods and services that are sold in the marketplace, and that does a relatively good job of it." ${ }^{\text {171 }}$

Second, Frankel posits various classes of environmental objectives, based on "the extent to which damage is localized around specific sources, as opposed to spilling out over a geographically more extensive area."172 One category of environmental objective should focus on 
addressing "environmental damage [from] pollution that is internal to the household or firm."173 In this instance, "what households in such countries primarily lack are the economic resources to afford stoves that run on cleaner fuels. In the case of internal pollution, higher incomes directly allow the solution of the problem."174 Property rights, according to Frankel, can be used to internalize potential externalities. Difficulties arise regarding commons areas, like tropical forest land where, in many poor countries, inadequate "institutional and economic resources to enforce laws protecting such resources" exist in conjunction with corrupt government officials. ${ }^{175}$ Another kind of environmental objective should concentrate on "national externalities, [which] include[] most kinds of air pollution and water pollution, the latter a particularly great health hazard in the third world." $" 176$ A further class of environmental objectives involves "international externalities," that encompass "environmental problems [which] cross national boundaries" like acid rain, where "some cooperation among countries is necessary." 177

Third, Frankel delineates the relationship between economic production and environmental impact by defining "three intermediating variables or channels of influence that can determine the aggregate economic impacts of trade or growth on the environment." "178 These three variables are as follows: (1) "[t]he scale of economic activity;", (2) "[t]he composition of economic activity;" "180 and (3) "[t]he techniques of economic activity." 181 Frankel uses these three variables to explain

173. Id. "Perhaps 80 percent (by population) of world exposure to particulates is indoor pollution in poor countries-smoke from indoor cooking fires-which need not involve any externality." Id.

174. Id. (endnote omitted).

175. Id. at 134 .

176. Id.

177. Id. "The strongest examples [of international externalities] are purely global externalities: chemicals that deplete the stratospheric ozone layer, greenhouse gases that lead to global climate change, and habitat destruction that impairs biological diversity. Individual countries should not expect to be able to do much about global externalities on their own." Id.

178. Id.

179. Id. at 135 . "[F]or physical reasons, more output means more pollution, other things equal. But other things are usually not equal." $I d$.

180. Id. "Trade and growth can shift the composition of output, for example, among the agricultural, manufacturing, and service sectors. Because environmental damage per unit of output varies across these sectors, the aggregate can shift." Id.

181. Id. Frankel states:

Often the same commodity can be produced through a variety of different techniques, some cleaner than others. Electric power, for example, can be generated by a very wide range of fuels and techniques. To the extent trade or growth involve the adoption of cleaner techniques, pollution per unit of GDP will fall.

Id. (endnote omitted) 
why the relationship between GDP and the environment is complex: "sometimes a country's growth is first bad for the environment and later good." ${ }^{\prime 82}$ Pursuant to his lucid and practical analysis, Frankel explains:

On the one hand, when GDP increases, the greater scale of production leads directly to more pollution and other environmental degradation. On the other hand, there tend to be favorable shifts in the composition of output and in the techniques of production. The question is whether the latter two effects can outweigh the first. ${ }^{183}$

Fourth, Frankel evaluates the so-called Environmental Kuznets Curve as another tool for understanding the achievement of environmental and economic objectives. As he points out: "For some important environmental measures, a U-shaped relationship appears: at relatively low levels of income per capita, growth leads to greater environmental damage, until it levels off at an intermediate level of income, after which further growth leads to improvements in the environment." 184 Frankel persuasively reasons that as countries become richer from the profits of early productive enterprises, they eventually reach a point where they can afford "to pay to clean up their environments." 185 Nonetheless, according to his astute and nuanced

\footnotetext{
182. Id.

183. Id.

184. Id. According to Frankel:
}

This label is by analogy with the original Kuznets Curve, which was a U-shaped relationship between average income and inequality. [According to empirical data] . . . this statistical finding for a cross section of countries . . . estimated that $\mathrm{SO}_{2}$ pollution peaked when a country's income was about $\$ 5,000-\$ 6,000$ per capita (in 1985 dollars). Most developing countries have not reached this threshold.

For countries where a long enough time series of data is available, there is also some evidence that the same U-shaped relationship can hold across time. The air in London was far more polluted in the 1950s than it is today. (The infamous "pea soup" fogs were from pollution.) The same pattern has held in Tokyo, Los Angeles, and other cities. A similar pattern holds typically with respect to deforestation in rich countries: the percentage of U.S. land that was forested fell in the eighteenth century and first half of the nineteenth century, but rose in the twentieth century.

Id. at 135-36 (endnotes omitted).

185. Id. at 136. Frankel explains the theory behind the Environmental Kuznets Curve as follows:

The standard rationale is thus that, at higher levels of income per capita, growth raises the public's demand for environmental quality, which can translate into environmental regulation. Environmental regulation, if effective, then translates into a cleaner environment. It operates largely through the techniques channel, encouraging or requiring the use of cleaner production techniques for given products, although regulation might also have a composition effect: raising the price of polluting goods and services relative to clean ones and thus encouraging consumers to buy more of the latter. 
analysis, just because the Environmental Kuznets Curve shows a statistical correlation does not mean that "the environment will eventually take care of itself." 186 Rather, Frankel pragmatically asserts that since most pollution "is external to the home or firm," higher incomes must meld with "effective government regulation, which usually requires a democratic system to translate the popular will into action" coupled with "the rule of law and reasonably intelligent mechanisms of regulation."187 Yet, as he acknowledges, at the transnational level, the law and politics for regulating "cross-border externalities" are more perplexing than at the national level of governance. ${ }^{188}$ An example of this cross-border complexity relates to carbon dioxide emissions. As Frankel concludes: "No Kuznets Curve has yet appeared for carbon dioxide," and "[e]ven though emissions per unit of GDP do tend to fall [over time on a national basis], this is not enough to reduce overall emissions, in the absence of a multilateral effort." 189

\section{Regulation}

Professor Frankel dissects a number of regulatory issues in preparation of his "main subject, the role of globalization per se."190 First, he observes that while "[i]t is logical to expect environmental regulation to cost something, to have a negative effect on . . productivity and income per capita," there are, nevertheless, economic tools to help policymakers choose wise regulatory initiatives. ${ }^{191}$ Thus, "[c]ost-benefit tests and cost-minimization strategies are economists' tools for trying to make sure that policies deliver the best environment for a given economic cost, or the lowest economic cost for a given environmental goal." ${ }^{\prime 192}$ On a continuum of most efficient to least efficient environmental interventions, Frankel praises taxes on energy, ${ }^{193}$

186. Id. Although with respect to pollution within homes (such as wood or coal cooking fires), increased household wealth will tend to alleviate internal pollution because the homeowners will be induced to use their increased wealth to purchase cleaner technology.

187. Id. For a fascinating and learned historical, political, and theoretical study of the rule of law ideal from the time of classical Greek and Roman writings to the present, see BRIAN Z. TAMANAHA, ON THE RUle OF LAW: History, POLITICS, THEORY (2004).

188. Frankel, supra note 140, at 136.

189. Id. at 137 .

190. Id.

191. Id.

192. Id.

193. Id. "Taxes on energy . . particularly on hydrocarbon fuels, are quite an efficient mode of environmental regulation (if the revenue is recycled efficiently)." Id. (internal quotation marks omitted). 
is lukewarm about mobile vehicle fuel efficiency standards, ${ }^{194}$ and denigrates "crude command and control methods"195 of environmental regulation. Indeed, he crisply observes that "[s]ome environmental regulations, when legislated or implemented poorly, can impose very large and unnecessary economic costs on firms, as well as on workers and consumers." 196

Second, in a penetrating and sagacious tenet, Frankel informs us that "[o]ccasionally there are policy measures that have both environmental and economic benefits" involving "win-win ideas [that] constitute the elimination of some previously existing distortion in public policy."197 Wasteful subsidy elimination exemplifies these powerfully effective government actions:

Many countries have historically subsidized the use of coal. The United States subsidizes mining and cattle grazing on federal land, and sometimes logging and oil drilling as well, not to mention water use. Other countries have substantial subsidies for ocean fishing. Elimination of such subsidies would improve the environment and save money at the same time - not just the federal budget, but for people's real income in the aggregate as well. ${ }^{198}$

Another win-win policy move "that would have economic and environmental benefits simultaneously would be to remove all barriers against international trade in environmental equipment and services, such as those involved in renewable energy generation, smokestack scrubbing, or waste treatment facilities." 199

Third, Frankel is skeptical about the school of thought that virtually any "tightening of environmental regulation stimulates technological

194. Id. He claims, in this regard, that "[d]ifferentiated CAFE standards for vehicles, for example, probably encouraged the birth of the SUV craze." Id. (parenthesis omitted).

195. Id. (internal quotation marks omitted). This is because, as Frankel clearly explains, "[g]overnment mandates regarding what specific technologies firms must use ... deny firms the flexibility to find better ways to achieve a given goal." Id. (parenthesis omitted).

196. Id.

197. Id. (internal quotation marks omitted).

198. Id. As Frankel candidly admits, however, politics often runs roughshod over economics: "Admittedly the economists' approach — taxing gasoline or making ranchers pay for grazing rightsis often extremely unpopular politically." Id.

199. Id. at 137-38. As explained by Frankel, this policy measure would result in a "double payoff" involving "the growth-enhancing effect of elimination of barriers to exports (in a sector where the United States is likely to be able to develop a comparative advantage), together with the environment-enhancing effect of facilitating imports of the inputs that go into environmental protection." Id. at 138. A "precedent," in this regard, according to Frankel, "is the removal of barriers to the imports of fuel-efficient cars from Japan, which was a clear case of simultaneously promoting free trade and clean air." Id. 
innovation and thereby has positive effects on both the economy and the environment." This hypothesis seems to assume, in Frankel's eyes, that wise, well-crafted government interventions in an economy are not important. $^{200}$

\section{Effects of Openness to Trade}

Professor Frankel elegantly instructs us that some effects of trade on the environment come about through economic growth and some effects of trade on the environment occur even for a given level of income. ${ }^{201}$ As to the former, more open trade "tends to raise income," and contributes to a society's economic growth. ${ }^{202}$ This, in turn, through operation of the Kuznets Curve, has a favorable impact on environmental quality over time. ${ }^{203}$ With respect to the latter, "effects of trade that do not operate via economic growth," Frankel indicates that " $[\mathrm{t}]$ hey can be classified in three categories: [1] systemwide effects that are adverse, [2] systemwide effects that are beneficial, and [3] effects that vary across countries depending on local competitive advantage." 204 First, regarding systemwide bad effects, Frankel labels this classification as the "race to the bottom hypothesis." ${ }^{205} \mathrm{He}$ summarizes this concern as follows: "[T]o the extent that countries are open to international trade and investment, environmental standards will be lower than they would otherwise be" because of concerns by political interest groups, like industry and labor, "that they will lose competitiveness against firms in other [environmentally lax] countries" if firms are saddled with costly environmental regulations. ${ }^{206}$

Second, regarding systemwide good effects, Frankel labels this classification the "gains from trade hypothesis." 207 He explains this supposition as follows: "Trade allows countries to attain more of what they want, which includes environmental goods in addition to marketmeasured output." $" 208$ This overall positive influence might come about

\footnotetext{
200. Id. This school of thought is closely associated with economist Michael Porter, and is, therefore, called the Porter Hypothesis. See id. (citing Porter and calling the school of thought the Porter Hypothesis).

201. Id.

202. Id.

203. Id.

204. Id. at 138-39 (internal quotation marks omitted).

205. Id. at 139 (internal quotation marks omitted).

206. Id.

207. Id. at 140 .

208. Id.
} 
through openness encouraging ongoing "technological and managerial innovation," as well as "an international ratcheting up of environmental standards" 209 spurred on by powerful international environmental standard-setters like the United States.

Third, with respect to differential effects arising from comparative advantage, Frankel refers to "[a]n oft-expressed concern ... that, to the extent that countries are open to international trade and investment, some will specialize in producing dirty products, and export them to other countries." ${ }^{210}$ As he goes on to explain:

The prediction is that the environment will be damaged more in this set of countries, as compared to what would happen without trade. The environment will be cleaner in the second set of countries, those that specialize in clean production and instead import the dirty products from the other countries. Leaving aside the possibility of a race to the bottom effect, the worldwide environment on average might even benefit somewhat, just as aggregate output should benefit, because of the gains from trade. But not everyone would approve of such a bargain. $^{211}$

\section{Potential Conflicts Between Globalization and Environmental Regulation}

Professor Frankel lucidly examines the so-called race to the bottom hypothesis in this portion of his essay. While he acknowledges that the "phenomenon can potentially put downward pressure on the regulatory standards of countries that compete internationally in trade and investment," the race to the bottom hypothesis "leaves much out." 12 Initially, "is the point that, for most of us, environmental quality is one goal, but not the only goal," since "we care also about income, and trade is one means of promoting economic growth" so these "goals often need to be balanced against each other.",13 Second, "[e]nvironmental concerns can be an excuse for protectionism," which can result in "less growth in trade and income" and "not even necessarily end up with a better environment." 214 Third, because foreign exporting firms are typically not "at the table" of national domestic policymaking, "environmental polices that are adopted on average can discriminate

211. Id.

212. Id. at 145 .

213. Id.

214. Id. 
against foreign firms relative to domestic firms, without anyone ever deliberately having supported a measure out of protectionist intent." 215 This structuralist problem is illustrated by Frankel in the Genetically Modified Organisms (GMO) agricultural dispute between the exporting firms of the United States and the importing countries of the European Union. Frankel provides useful and practical insight when he urges:

Whatever the source of different perceptions [regarding the environment] across countries, it is important to have a set of internationally agreed rules to govern trade, and if possible a mechanism for settling disputes that arise. That is the role of the WTO. The need for such an institution does not vanish when environmental issues are a part of the dispute. Certainly if one cares at all about trade and growth, then one cannot automatically sign on to each and every campaign seeking to block trade on environmental grounds. But even if one cares solely about the environment, claims need to be evaluated through some sort of neutral process. ${ }^{216}$

\section{International Agreements and Institutions}

Professor Frankel completes his perspicacious think piece with some helpful observations and recommendations. On the topic of multilateral environmental organizations, he offers a wide-eyed-realist take that "there is very little support among the world's governments for a powerful multilateral agency in the area of the environment" because "[t]hey fear infringement on their sovereignty." bilateral and regional fair trade agreements (FTAs), he observes that these more limited types of international undertakings "have incorporated environmental components more often than have multilateral agreements." ${ }^{218}$ Frankel sees a pragmatic reason for this phenomenon: "Whether because of cultural homogeneity or the small numbers involved, a group consisting of a few neighbors is usually readier to contemplate the sort of deep integration required for harmonization of environmental standards than are negotiators in groups with more than 100 diverse members, such as the WTO." 119 And on the

\footnotetext{
215. Id. at 146

216. Id. at 146-47. Frankel also argues for an internationalist approach with regard to global environmental problems like carbon dioxide emissions, loss of biodiversity, depletion of the stratospheric ozone shield, sulfur dioxide emissions leading to acid rain, and other concerns. Id. at 150

217. Id. at 151

218. Id. at 152 .

219. Id. (internal quotation marks omitted).
} 
topic of WTO panel rulings, Frankel points out that the environmentalists' "[p]erceptions that [these] . . . rulings have interfered with the ability of individual countries to pursue environmental goals are poorly informed." 220 As he notes:

In cases such as Canadian asbestos, Venezuelan gasoline, and Asian shrimp, the rulings have confirmed that countries can enact environmental measures, even if they affect trade and even if they concern others' Processes and Production Methods (PPMs), provided the measures do not unnecessarily discriminate among producer countries. $^{221}$

\section{Kent Jones's Call for Long-Sighted Institutional and Cooperative Environmental Globalization}

Professor Kent Jones, in his succinct and tightly reasoned book, Who's Afraid of the WTO?, ${ }^{222}$ provides a cool-headed response to the misinformed and exaggerated protests leveled against the WTO, in particular, and globalization, in general. In a series of informative and persuasive chapters leading up to his ultimate conclusion and set of twelve recommendations, ${ }^{223}$ Jones covers much ground. He analyzes such timely topics as: why countries trade and join the WTO; ${ }^{224}$ the nature of trade protectionism; ${ }^{225}$ the WTO and its interface with national sovereignty; ${ }^{226}$ human rights, labor concerns, and trade ${ }^{227}$ developing countries and trade; ${ }^{228}$ and NGOs, MNCs, and trade. ${ }^{229}$ His chapter on trade and the environment ${ }^{230}$ is particularly clearheaded and will be the focus of my discussion in the remaining section of this Part of the Article. But before exploring Jones's chapter on trade and environmental dynamics, a brief synopsis of his more general, contextual exegesis about the WTO is in order.

\footnotetext{
220. Id. at 160 .

221. Id.

222. Kent Jones, WhO's AFRAID OF THE WTO? (2004).

223. Id. at $186-201$.

224. Id. at $33-47$

225. Id. at $48-65$.

226. Id. at $92-104$.

227. Id. at 125-46.

228. Id. at 147-66.

229. Id. at $167-85$.

230. Id. at 105-24.
} 


\section{Why the WTO Is Under Fire}

According to Jones, "[i]t is ironic that the WTO, with nearly universal membership and a strong consensus on the benefits of trade, should generate such [extraordinary] controversy." ${ }^{231}$ As he explains:

All of the recent turmoil surrounding the WTO contrasts sharply with the staid image of multilateral trade diplomacy in general and a history of trade negotiations played out in relative obscurity. The organization was established in 1995 as part of the set of agreements reached in the Uruguay Round of trade negotiations that had begun in 1986. The WTO's predecessor was the General Agreement on Tariffs and Trade (GATT), founded in 1947 as part of a new postwar economic order that also included the World Bank and the International Monetary Fund. Over the next [five decades], the GATT sponsored eight rounds of trade negotiations that reduced average industrial tariffs among its members from 40 percent to just 3 percent. The GATT began with just twenty-nine members . . . including the United States, the United Kingdom, other European countries, Canada, and a small number of developing countries. Its membership grew to 131 countries by the end of the Uruguay Round, and the WTO as of 2003 included 146 member countries. ${ }^{232}$

Professor Jones points out that the WTO has become "a lightning rod" for "anxieties and fears" concerning globalization. ${ }^{233}$ Although "global trade policy rules can coexist with and reinforce social and environmental goals," Jones contends that "an expanded set of international agreements" and "new global institutions" will be required to reconcile trade, the environment, and other social aspirations. ${ }^{234}$

Engaging in a fascinating taxonomical exercise, Professor Jones differentiates between what he calls "WTO bashers," on the one hand, and "WTO skeptics" on the other hand. ${ }^{235}$ The former, says Jones, "tend

231. Id. at 4 .

232. Id. Jones informs us that the WTO is a limited organization with little flexibility: The WTO is an organization based on a consensus among its members that countries benefit from trading with each other, and the members are therefore willing to promote trade through multilateral negotiations and a system of trade policy rules and dispute settlement. Only governments can be members of the WTO, and all of the rules, negotiations, and procedures are driven by consensus: no rights or obligations can accrue to any member country without the implicit agreement of the entire membership. This principle keeps the organization focused on the one issue that forms the basis of that Id. consensus: the mutual gains from trade.

233. Id. at 5 .

234. Id.

235. Id. 
to be ideologically opposed to capitalism and therefore see irreconcilable conflicts between human rights, social justice, and the global environment . . . and a market-driven trading system . . . . For them, it seems, the conflict over the WTO is akin to a struggle of good versus evil, with no compromise possible.,"236

The "WTO skeptics," however,

are in principle concerned about the impact of globalized markets on their jobs and the state of the world, and they question the role of the WTO in a world of multidimensional issues and problems. They fall into a number of different groups, based on both economic and noneconomic interests and priorities. Some, for example, are worried about losing their jobs as a result of international competition; others own factories and capital assets threatened by imports. Still others see the profit motive associated with international trade as a dangerous force that is being allowed to override environmental and social concerns. $^{23}$

Jones makes another vital point in his discussion of sovereignty; he makes a distinction between multilateral conceptions of fair trade versus unilateral conceptions. He argues that, as a fundamental matter, "a global trading system must rest on a multilateral, not a unilateral, notion of what is fair, unless one dominant country or group of countries can call the shots and force the others to follow."238 As Jones sees it, "[m]orally based unilateral trade sanctions represent a slippery slope in trade policy because all countries can find moral flaws in the policies of other countries if they look hard enough.," 39 As he recommends: "[w]hat is needed is a way to identify compelling global policy issues on the basis of broad consensus, scientific evidence where applicable, and systematic, coordinated action." 440 Furthermore, "[t]wo additional objections to unilateral action are that such measures will either be ineffective, weakening the credibility and resolve of countries to address the issue systematically, or if they are effective, that they will do more harm than good."241 Thus, Jones persuasively contends, in this regard, that

\footnotetext{
236. Id.

237. Id.

238. Id. at 98.

239. Id.

240. Id. at $98-99$.

241. Id. at 99 .
} 
[t]he Law of Unintended Consequences would often intervene. Thus, attempts to eliminate poverty by enforcing a worldwide minimum wage with trade restrictions would most likely increase unemployment and poverty. A trade ban on goods made with child labor may very well increase child prostitution. Environmental antidumping regulations that prevent poor countries from exporting certain goods would typically reduce economic growth and possibly lead to greater deforestation as alternative fuels are no longer affordable. ${ }^{242}$

\section{Trade Policy and the Environment}

Professor Jones observes that " $[\mathrm{m}] \mathrm{uch}$ of the emotional opposition to the WTO in recent years has been fueled by the view that it is essentially an antienvironmental organization." 243 Yet, "[a]11 is not as it appears to be" because "[a]side from the wildly exaggerated perception of the WTO as an unelected world government, imposing the will of multinational corporate polluters on the world's population, there is widespread misunderstanding about the [alleged negative] relationship between trade and the environment." 244 Jones emphasizes, in this regard, "green language" in the 1994 press release, which the WTO issued near the time of its founding. ${ }^{245} \mathrm{He}$ seems a bit defensive - and decidedly unpragmatic - however, when he argues:

The [WTO's] Committee on Trade and the Environment (CTE), for its part, has provided a valuable forum for discussions on reconciling environmental and WTO treaty obligations and other crossover issues. However, it has not produced concrete proposals for trade policy reform to enforce or promote environmental goals because it has no institutional mandate to do so. $^{246}$

But why can't the WTO's CTE exercise some leadership in the difficult area of trade and the environment where it has expertise and prestige? While it may be true, as Jones asserts, that current "trade-andenvironment policy issues go beyond the limits of an identifiable

\footnotetext{
242. Id.

243. Id. at 105 .

244. Id. at 106 .

245. Id. Jones quotes from a 1994 press release issued by the WTO, which stated: “'[T]here should not be, nor need be, any policy contradiction between upholding and safeguarding an open, non-discriminatory and equitable multilateral trading system on the one hand, and acting for the protection of the environment and the promotion of sustainable development on the other." $I d$. (alteration in original) (quoting Press Release, World Trade Organization, The Structure and Organization of Work During the Transition from the GATT to the WTO (June 24, 1994)).

246. Id. at 107 .
} 
[present] WTO consensus," 247 why does the CTE not try harder and attempt to be an honest broker in proposing to WTO member states rules and guidelines for heading off disputes before they reach the claim and arbitration stage? Why wait for other international "processes and institutions to resolve conflicts between trade and environmental goals" ${ }^{248}$ when the future is now? On this point, the logic of such scholars as Carlos A. Calderin and Sanford E. Gaines-both of whom resist the formation of a world environmental organization to "solve" the disconnects between trade and environmental issues ${ }^{249}$-is more pragmatic than Jones's attempt to engineer an end run around the real world complexity of the trade-environment problem. As explained by Gaines, "[t] he existence of a [Global Environmental Organization (GEO) or its functional equivalent] seems . . . more likely to allow the WTO to continue to avoid trade policy reform by pushing governance responsibility off onto the environmental community." ${ }^{, 250}$ Rather, according to Gaines, "[t]he remedy for that problem is an organized effort to educate trade policy makers and institutional and organizational arrangements that keep the pressure on the WTO to make suitable policy changes." 251

Professor Jones's discussion of the dispute resolution dynamic of the WTO gets back to a pragmatic tack after his mushy thinking about the need for a separate GEO. After briefly discussing some of the more celebrated recent WTO Dispute Settlement Body (DSB) decisions, like the tuna/dolphin controversy and the shrimp/turtle disagreement, Jones points out that, "[i]n general, political confrontation over the WTO can often be avoided by identifying common sense alternative measures to

\footnotetext{
247. Id. at 108 .

248. Id.

249. See Gaines, supra note 95, at 342-85 (arguing that a global environmental organization would be ineffective). See generally Charles A. Calderin, The Emergence of a Responsible Green World Trade Organization: Why Creating a World Environment Organization Would Hinder This Goal, 8 U.C. DAVIS. J. INT'L L. \& POL'Y 35 (2002) (arguing that a world environment organization would not protect and preserve the environment).

250. Gaines, supra note 95, at 377.

251. Id. Professor Gaines offers several steps of "bridge-building" between trade officials and the environmental community. Id. at 380-82. Regarding the potential utility of the WTO's CTE, Gaines asserts:

Already, the WTO Committee on Trade and Environment provides a ready occasion for . . . involvement [of environmental officials into the trade policy deliberation process].

More and more governments are bringing their environmental officials to the table at the CTE, and the WTO has accredited a number of international environmental organizations as observers at the CTE meetings, and has invited them to speak on occasion. Id. at 380 .
} 
defuse or resolve the underlying conflict"252 in a cost-effective and reasonable manner. Jones's commentary on the beef-hormone dispute and the precautionary principle is, likewise, practical and insightful. As he explains, "[t]he European Union had banned the import of U.S. hormone-treated beef, and the United States had argued that such hormones were safe and left no damaging effect."253 The United States won on this legal issue before the WTO. ${ }^{254}$ According to Jones's balanced and judicious analysis of the beef-hormone controversy:

There is an important principle at stake in the decision: in the absence of scientific evidence, should countries be allowed to use a precautionary principle to exclude imports at their discretion? The clear danger is that much mischief could result if WTO rules were rewritten to allow countries unilaterally to restrict imports based on the perception that something is amiss in the way the imports were produced. Instead of unilaterally invoking a precautionary principle, assembling an international panel of experts to judge the merits of such cases would be far more credible. This may not be easy if the issue has become politicized. However, the point is that unilateral declarations of scientific judgment without supporting evidence will never be a viable principle in any rules-based system.

The chief reason why Jones's analysis of trade and environment issues is so lucid and concrete is his astute observation that there are usually "ways to resolve the issues without resorting to trade restrictions or a general assault on the world trading system." 256 As he pragmatically summarizes:

Depending on the situation, countries can often avoid trade conflicts by revising their environmental legislation to eliminate discriminatory trade effects, by providing foreign aid or technical expertise to countries where the environmental problem exists, by negotiating a

\footnotetext{
252. JONES, supra note 222, at 110.

253. Id. at 111 .

254. Id.

255. Id. at 111-12. Jones cuts through the knot of the beef-hormone controversy with the following practical prescription:

It seems that suspicions regarding hormone-treated beef have some popular support in Europe, encouraged in no small part by European beef producers. Yet if this is the main reason for the government's import ban, then an equally effective policy would be to allow the imports but to require a label on the beef in question stating the use of hormones in the cattle. In this manner, the consumer would ultimately be able to decide, at least until such time that any strong scientific evidence provides the basis for stricter regulation.

Id. at 112 (endnote omitted).

256. Id. at 117 .
} 
system of labeling for the products, or by setting up environmental codes of conduct for multinational corporations. ${ }^{25}$

Moreover, Jones is optimistic about solving international environmental disagreements between nation-states because of the value of liberalized trade to all trading partners. As he explains, "instead of using trade primarily as a weapon to force compliance with environmental measures, the institutional approach suggests the value of trade as a positive incentive to induce voluntary compliance" with multinational environmental norms. ${ }^{258}$ "In other words," according to Jones, "global environmental protection will require further trade liberalization."259 Indeed, "the WTO may yet emerge as an important component in the process, not through the imposition of an environmental chapter, but through its ability to harness the gains from trade as a positive bargaining chip for achieving globally acceptable environmental goals." 260 The vital "point in this regard is that a cooperative approach is likely to produce more progress than confrontation, threats, and punishment." ${ }^{, 261}$

\section{SOME PRINCIPLES OF GLOBOECOPRAGMATISM}

We have examined the differing views of six prominent writers on globalization, in general, and on international trade and environment conflicts, in particular. ${ }^{262}$ Now, it is time to synthesize these views into what I call principles of globoecopragmatism: a practical, tradeenhancing, environmentally protective legal strategy. In the course of

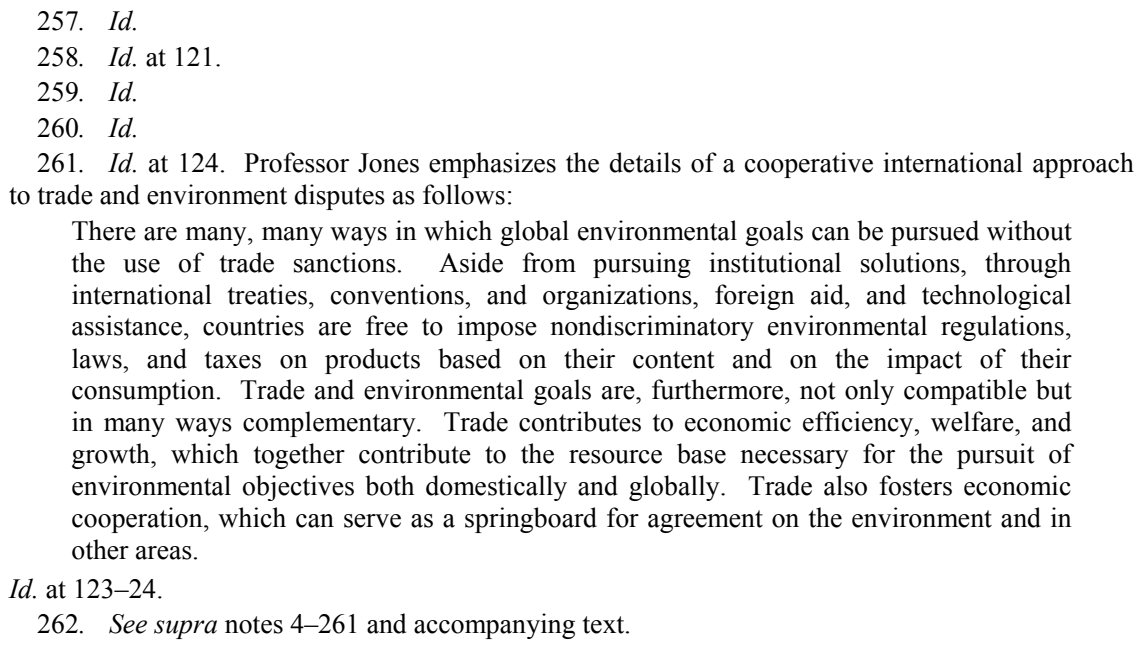

There are many, many ways in which global environmental goals can be pursued without the use of trade sanctions. Aside from pursuing institutional solutions, through international treaties, conventions, and organizations, foreign aid, and technological assistance, countries are free to impose nondiscriminatory environmental regulations, laws, and taxes on products based on their content and on the impact of their consumption. Trade and environmental goals are, furthermore, not only compatible but in many ways complementary. Trade contributes to economic efficiency, welfare, and growth, which together contribute to the resource base necessary for the pursuit of environmental objectives both domestically and globally. Trade also fosters economic cooperation, which can serve as a springboard for agreement on the environment and in other areas.

$I d$. at $123-24$.

262. See supra notes 4-261 and accompanying text. 
formulating these principles of globoecopragmatism, I will take the liberty of drawing upon a few additional texts.

\section{A. The Funnel of Pragmatism on Global Trade and the Environment}

As Professor Daniel Farber so eloquently put it: "One of the lessons of pragmatism is the usefulness of combining concrete examples with more abstract forms of reasoning."263 Farber points out in this regard:

Consideration of concrete situations serves several purposes. It provides a method of testing and refining ethical principles. For instance, according to John Rawls, the best moral reasoning involves a movement between general theories and intuitions about specific issues. The general theories are tested for their fit with specific intuitions, which are themselves subject to modification if they cannot be made part of some coherent theory.

Indeed, in a similar fashion to Farber's insights, Professors William N. Eskridge, Jr., Philip P. Frickey, and Elizabeth Garrett offer a pragmatic approach to the task of statutory interpretation, which can also help to shed some light on a pragmatic approach to trade and environmental issues. They contend that "our intellectual framework is not single-minded, but consists of a 'web of beliefs,' interconnected but reflecting different understandings and values." 265 Thus, "[a]s a consequence, human decisionmaking tends to be polycentric, spiral, and inductive, not unidimensional, linear, and deductive." ${ }^{\text {266 }}$ Eskridge, Frickey, and Garrett cite the writings of one of the founders of American pragmatism, Charles Peirce, ${ }^{267}$ for the metaphor that pragmatic reasoning

263. DANiel A. FArber, Eco-Pragmatism 15 (1999) (emphasis added). Farber then cites to John Rawls, id., and quotes another legal theorist for the supporting proposition that "practical reason seems always to involve a combination of something general with something specific so that judgment mediates between the general standard and the particular case." Id. n.2 (internal quotation marks omitted) (punctuation modified) (quoting Frank I. Michelman, The Supreme Court, 1985 Term-Foreward: Traces of Self-Government, 100 HARV. L. REV. 4, 28 (1986)).

264. Id. at 15 .

265. William N. Eskridge, JR., Philip P. Frickey \& Elizabeth Garrett, Legislation and STATUTORY INTERPRETATION 240 (2000).

266. Id.

267. See, e.g., Charles Sanders Peirce, Pragmatism as a Principle and Method of Right ThInKING (Patricia Ann Turrisi ed., 1997) (containing Peirce's manuscripts for lectures on pragmatism). See generally CHRISTOPHER HOOKWAY, PEIRCE (discussing Peirce's philosophical views and how those topics fit together as a whole). "The term 'pragmatism' was introduced into the discourse of philosophers by Charles Sanders Peirce in 1878, to express a complex of ideas about logic (good thinking) which he had developed since 1867." John Finnis, Natural Law: The Classical Tradition, in THE OXFORD HANDBOOK OF JURISPRUDENCE AND PHILOSOPHY OF LAW 1, 31 (Jules Coleman \& Scott Shapiro eds., 2002). 
should not be like a chain (no stronger than its weakest link) but, rather, should be like a cable of interconnected fibers; ${ }^{268}$ thus, they conclude that "the goals of statutory interpretation may be multiple and the sources may be various." 269

We can draw upon the Eskridge-Frickey-Garrett methodology and the Farber insights about pragmatic legal reasoning ${ }^{270}$ to play off relatively concrete considerations with relatively abstract considerations involving global trade and the environment. The result of this analogical analysis coupled with a synthesis of the thoughts explored in Parts II and III of this Article is the following "funnel.,"271

\footnotetext{
268. ESKRIDGE, FRICKEY \& GARRETT, supra note 265, at 240 (citation omitted).

269. Id.

270. See supra notes 263-69 and accompanying text.
}

271. I credit Professors Eskridge, Frickey, and Garrett for inspiring the use of this funnel of pragmatism. For statutory interpretation techniques, see the "Frickey and Eskridge Funnel of Abstraction." See ESKRIDGE, FRICKEY \& GARRETT, supra note 265, at 241 (incorporating a diagram from William N. Eskridge, Jr. \& Philip P. Frickey, Statutory Interpretation as Practical Reasoning, 42 Stan. L. REV. 321, 345-62 (1990)). I view the Blomquist Funnel of Pragmatism on Global Trade and the Environment to be a useful way to play off relatively concrete considerations with relatively abstract considerations. This is a Rawlsian and a Farberian insight of pragmatism. See supra notes 263-64 and accompanying text. Professor Jim Chen, however, has suggested that - unlike the Eskridge-Frickey funnel of abstraction for statutory interpretation techniques - the Blomquist Funnel of Pragmatism on Global Trade and the Environment is different from "the hydraulic relationship between authority and cogency, that informed [the Eskridge-Frickey] project." E-mail from Jim Chen, Associate Dean for Faculty and James L. Krusemark Professor of Law, University of Minnesota Law School, to Robert F. Blomquist, Professor of Law, Valparaiso University School of Law (Jan. 12, 2006, 16:26 CST) (on file with author). I concede that there is not a perfect theoretical fit between the Eskridge-Frickey funnel of abstraction for statutory interpretation techniques and the Blomquist Funnel of Pragmatism on Global Trade and the Environment. I view the EskridgeFrickey funnel to be an inspiring and edifying metaphor for my own funnel. 
The Blomquist Funnel of Pragmatism on Global Trade and the Environment

Figure 1

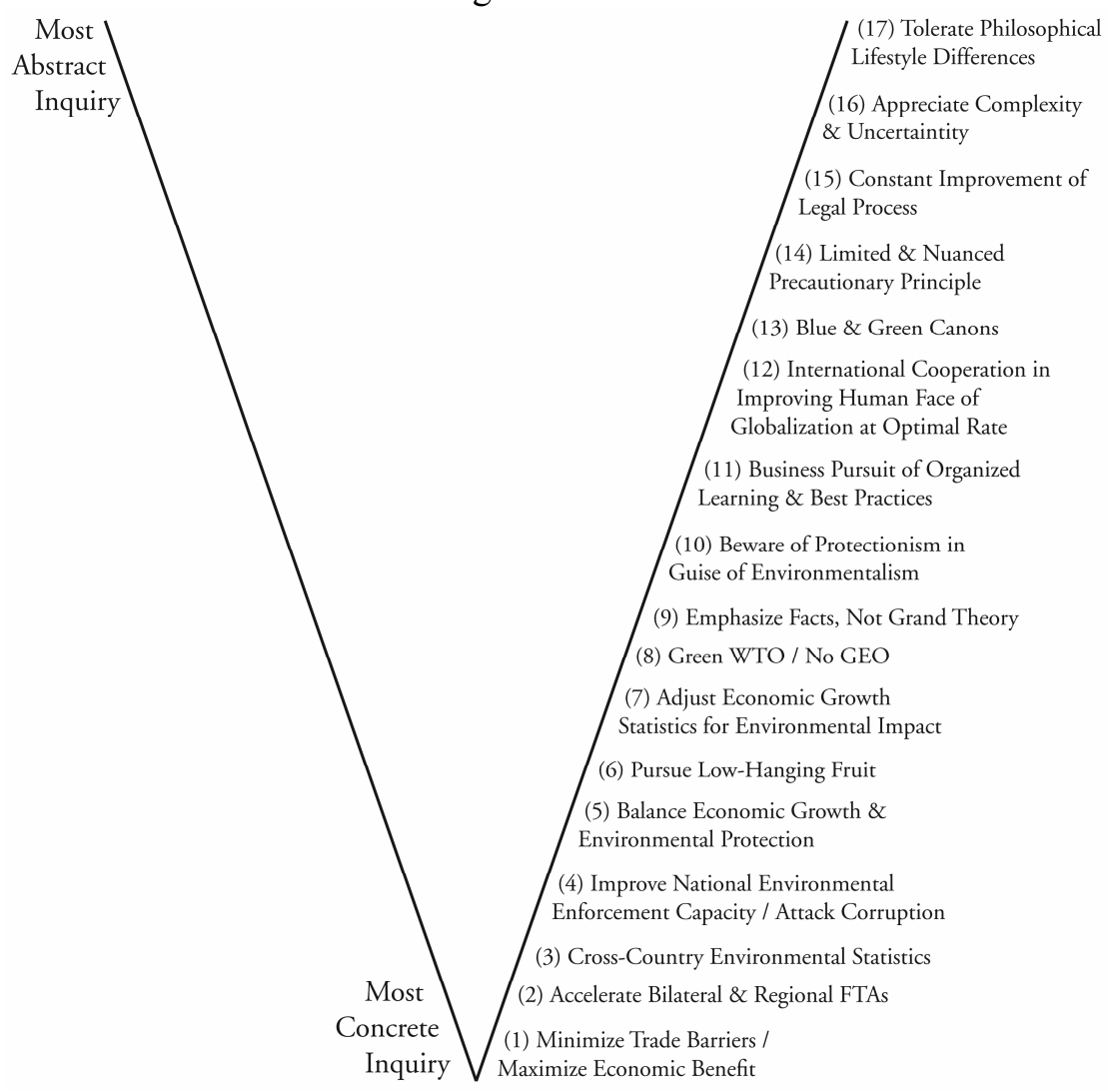

\section{B. Key Pragmatic Principles}

Our analysis and synthesis yields seventeen pragmatic principles for approaching problems of global trade and the environment on a "funnel" of pragmatism-ranging from the most concrete inquiry to the most abstract inquiry. ${ }^{272}$ What follows is a brief explanation of these principles starting at the tip of the funnel (most concrete) and working up to the upper cone of the funnel (most abstract).

272. See supra notes $262-71$ and accompanying text (discussing the funnel of pragmatism). 


\section{Minimize Trade Barriers/Maximize Economic Benefit}

The most concrete principle is all about the well-documented macroeconomic and microeconomic gains in income from increased levels of trade (based on the doctrine of comparative advantage and specialization of production) linked with the inverse relationship between lower trade barriers and higher levels of trade and further concatenated with the Environmental Kuznet Curve (demonstrating steady environmental improvement of most pollutant emissions after a society reaches a minimal level of per capita income). ${ }^{273}$ Thus, the opening gambit in the globoecopragmatism project should be tariff slashing and nontariff trade-barrier-busting proposals by trade negotiators. A worthy example of this point is the offer by U.S. Trade Representative Rob Portman and U.S. Agriculture Secretary Mike Johanns in October of 2005 to slash developed-nation farm subsidies as part of the Doha Round of WTO negotiations. ${ }^{274}$

\section{Accelerate Bilateral and Regional FTAs}

Moving up the funnel of pragmatism on global trade and the environment, nations should seek as many bilateral and regional FTAs that incorporate environmentally protective commitments as are feasible and prudent. The relatively small numbers of international trade partners and the relatively more homogenous cultural context make negotiation of

273. See supra notes $31-32,38-39,45-46,48-50,183-89,197-99,249-51$ and accompanying text (discussing the relationship between the economy and the environment).

274. Stephen J. Norton, WTO Talks Get a Jolt from U.S. Challenge, 63 CONG. Q. WKLY 2822, 2822 (2005). Thus:

Just weeks ahead of a high-level December [2005] meeting in Hong Kong [of WTO national representatives], U.S. Trade Representative Rob Portman and Agriculture Secretary Mike Johanns on [October] 10 offered to cut price supports for U.S. farmers by 60 percent, eliminate export subsidies and limit tariffs on some protected products, such as sugar. ...

In exchange, other countries, many of which have much higher tariffs and subsidies than the United States, would have to be just as bold. The 25-nation European Union, for example, would have to cut its far more generous subsidies by 80 percent. All countries would have to shrink tariffs and open their markets to U.S. agriculture goods.

... Industrial countries are under increasing political pressure - as well as the threat of costly trade sanctions-from poor nations that say they want a more competitive marketplace for agricultural goods. 
these agreements easier than the deep integration demanded by scores of diverse nation-states. ${ }^{275}$ A commendable bilateral FTA with explicit environmental standards is the agreement signed between the United States and the Hashemite Kingdom of Jordan in October of 2000, and an admirable trilateral example is the successful negotiation and agreement between Canada, Mexico, and the United States comprising the North American Free Trade Agreement (NAFTA) and its Environmental Side Agreement in the early 1990 s. $^{276}$

\section{Develop Cross-Country Environmental Statistics}

Another concrete principle of globoecopragmatism is the advisability of developing, utilizing, and refining cross-country environmental statistics on how economic growth from freer trade impacts environmental objectives. These comparative data would provide quantification of trade-linked environmental benefits and degradations that will help policymakers better understand which environmental externalities need to be ameliorated. ${ }^{277}$ It is heartening, for example, that existing statistics show that increased international trade flows help reduce $\mathrm{SO}_{2}$ emissions. Conversely, it is disquieting that cross-country statistics show that global greenhouse emissions are not moderated by international trade. ${ }^{278}$

\section{Improve National Environmental Enforcement Capacity/Attack Corruption}

Still quite concrete as a mode of inquiry and action is the principle that pragmatic global trade and environmental policy should improve the institutional capacity of relatively poor countries to better enforce their own domestic environmental laws in order to diminish national externalities, while simultaneously focusing on attacking corruption by government officials. ${ }^{279}$ Regarding government corruption, for instance, the Copenhagen Consensus project in 2004 identified this matter as one of the most serious problems facing the world today with "world-wide

\footnotetext{
275. See supra notes 217-19 and accompanying text (discussing Frankel's views on FTAs incorporating environmental components).

276. See Blomquist, supra note 49, at 751 (discussing these FTAs).

277. See supra notes 159-63 and accompanying text (discussing statistics of environmental benefits).

278. Id.

279. See supra notes $173-75$ and accompanying text (discussing need to internalize potential externalities).
} 
bribery totals at least $\$ 1$ trillion per year, just over 3 [percent] of the world income in 2002." 280

\section{Balance Economic Growth and Environmental Protection Values}

It is decidedly unpragmatic to put zero weight on income that can be earned from trade and place an infinite weight on environmental values. In many concrete situations involving specific facts, it makes sense to fashion policy decisions that are more protective of the environment and to require those private firms involved in a particular pattern of trade to internalize the environmental protection costs and pass them on to importers. Both economic earnings from expanded trade and environmental quality are worthwhile social objectives; we can enjoy a combination of both and the true challenge is for policymakers to find the best tradeoff. ${ }^{281}$

\section{Pursue Low-Hanging Fruit}

While it is a bit abstract to urge a search for the most efficient mix of trade and environmental policies - the least-costly-most-effective measures or "low-hanging fruit"-this mode of inquiry takes on concreteness in specific contexts. Thus, because trade sanctions in the service of environmental protection are notoriously economically wasteful and often counterproductive, policymakers should consider cheaper and more effective ways of achieving environmental objectives. By way of two prominent examples: instead of banning hormone-fed beef, governments should mandate accurate product labeling so that consumers can make their own individual choices of what kind of meat to put on their dinner tables; instead of banning fish products caught by poor-nation fishermen because the process or method of harvesting fish is harmful to other marine life of concern (like dolphins or sea turtles), richer nations should provide transfer payments to help the destitute fishermen buy the more sophisticated technology. ${ }^{282}$

280. Susan Rose-Ackerman, Governance and Corruption, in GlOBAL CRISES, GLOBAL SOLUTIONS, supra note 32 , at 301, 301 .

281. See supra notes 126-32, 165-71, 212-13 and accompanying text (discussing the necessity to balance economic earnings from expanded trade and environmental quality).

282. See supra notes 27-29, 37-39, 135-39, 143-44, 150-58, 190-96, 200, 220-21, 252-53, 256-57 and accompanying text (discussing various environmental and trade regulations). 


\section{Adjust Economic Growth Statistics for Environmental Impact}

While the undertaking is abstract at the moment because of our relatively crude and inexact methods of measuring environmental damages (and cognate ecosystems services), ${ }^{283}$ we must take more vigorous steps to find principled ways of adjusting economic growth rates for environmental degradation since unmeasured, environmentally destructive growth is simply not an accurate yardstick of human flourishing. Only with improved, focused, and more robust ways of gauging environmentally sustainable and environmentally unsustainable trade income will we be able to make concrete changes in production processes and trading arrangements. ${ }^{284}$

\section{Green the WTO and Forget About Forming a GEO}

We should work for and embrace further multilateral environmental agreements (MEAs) among nations to address continuing unresolved global and international environmental spillovers and global resource issues. ${ }^{285}$ At the same time, we should focus efforts on "greening" the WTO - a concerted effort to educate trade policymakers and to fashion suitable institutional and organizational innovations that moderate trade rules to be more protective of environmental concerns. Dreaming up a separate and competing GEO as an end run around the real world complexity of the trade-environment problem is too abstract by half. ${ }^{286}$ The WTO's recent efforts in reinvigorating its CTE and in its Appellate Body's turn toward creative resolution of trade and environmental conflicts are two examples of concrete efforts to recalibrate the equilibrium between these two important concerns. ${ }^{287}$

283. See, e.g., FINDLEY ET AL., supra note 139, at 796-801 (collecting and discussing materials addressing government recovery for damages for injury to natural resources); id. at 872-81 (collecting materials that discuss "economic services" of various intact and functioning ecosystems).

284. See supra notes 129-30, 170-71 and accompanying text (discussing need for measure of environmental impact from economic trade).

285. When we pause to assess the record of progress in international environmental treatymaking over the last four decades, the nations of the world deserve credit for a remarkable number of MEAs on a wide array of problems. See AlEXANDRE Kiss \& DinAH SHELTON, InTERNATIONAL ENVIRONMENTAL LAW xiii-xxix (1991) (chronological list of MEAs).

286. See supra notes 48-50, 249-51 and accompanying text.

287. Blomquist, supra note 49 , at $743-45,752$. 


\section{Emphasize Facts, Not Grand Theory}

This mode of inquiry for resolving trade and environmental conflicts is at the midpoint of our funnel of pragmatism - halfway between the most concrete consideration at the tip of the funnel and the most abstract consideration at the top of the funnel. This is the case because this factor - emphasizing facts, not grand theory - is equally abstract (what does it really mean in the real world?) and concrete (specific cases will bring forth the particular facts that we should address). In a sense, this principle is more of an attitude or mood which posits that the most fruitful way to approach trade and environmental issues is to withhold, in a disciplined fashion, broad-sweeping generalizations while avoiding knee-jerk imputations of bad motives and be willing to search for facts and insist on precise conceptual thinking. ${ }^{288}$ For example, Public Citizen is at its best when it offers specific criticisms of the Uruguay Round tariff schedules that provide counterproductive "incentives for rip and ship exploitation of natural resources" and specific objections to the content of WTO-led policies that destroy forests. ${ }^{289}$ Conversely, Public Citizen's generalized trade-bashing rhetoric is of no use in resolving real trade and environment problems. ${ }^{290}$

\section{Beware of Protectionism in the Guise of Environmentalism}

It is a fact of political life that domestic interest groups will try to rent-seek and lobby national politicians for as much trade protection as they can get. Therefore, like the classical Greek explorer Odysseus (who was an expert at pragmatically coping with his uncertain world), ${ }^{291}$ we need to fashion and improve global legal institutions and mechanisms

\footnotetext{
288. See supra notes 56-62, 77-78, 167, 170-71, 178-83 and accompanying text (asserting the importance of focused thinking).

289. See supra notes 59-61 and accompanying text.

290. See supra notes 56-58 and accompanying text.

291. Judge Richard A. Posner, in a wonderful reflection on Odysseus, writes: [What] is odd about the protagonist, and the implicit values, of the Odyssey from the orthodox standpoint is that Odysseus is not a conventional hero, the kind depicted in the Iliad. He is strong, brave, and skillful in fighting, but he is no Achilles ... or even Ajax; and he relies on guile, trickery, and outright deception to a degree inconsistent with what we have come to think of as heroism or with its depiction in the Iliad. His dominant trait is skill in coping with his environment rather than ability to impose himself upon it by brute force. He is the most intelligent person in the Odyssey but his intelligence is thoroughly practical, adaptive. Unlike Achilles in the Iliad, who is given to reflection, notably about the heroic ethic itself, Odysseus is pragmatic. He is an instrumental reasoner rather than a speculative one.

Richard A. Posner, LAW, PRAgmatism AND DEMOCRACy 27 (2003) (all but first emphasis added).
} 
that will prevent us from being lured by the Sirens of domestic rentseekers onto the rocks of trade protectionism. The WTO and other trade agreements between nation-states provide the functional equivalent of Odysseus ordering his compatriots to bind him to the Calypso's mast in the presence of the alluring Sirens: international trade rules, agreed on in advance by nation-states, are neutral methods of avoiding the structural tendency of domestic business firms to curry favor with domestic politicians in exchange for trade discriminatory measures (some subtle, some in the guise of protecting the environment, and even some unintentional). ${ }^{292}$ Therefore, we need to cope with the relatively abstract matter of domestic rent-seeking and trade protection with relatively concrete international trade rules.

\section{Business Pursuit of Organized Learning and Best Practices}

It is somewhat abstract to utilize Environmental Lateral Pressure theory-involving the three critical variables of population, technology, and resources - to gain the insight that global trade tends to provide an unsavory mechanism for rich countries to push off their environmental costs of industrialization onto poor countries. ${ }^{293}$ Yet, it is fairly concrete to realize the ways that MNCs can ameliorate this problem. MNCs should seek, and be encouraged to pursue, organized learning and the best practices of environmentally protective production measures. ${ }^{294}$ This matter would appear to be a tantalizing opportunity for the WTO's CTE to convene conferences, publish sector-specific, environment-best practices, and gather statistical data. ${ }^{295}$

292. See supra notes 214-16 and accompanying text (explaining how policymakers should not give in to protectionist arguments using environmental concerns as an excuse).

293. See supra notes $86-102$ and accompanying text (discussing the downsides of globalization and Lofdahl's Environmental Lateral Pressure model).

294. See supra notes 81-85 and accompanying text (detailing examples of corporations following best practice measures).

295. See supra notes $277-78$ and accompanying text (commenting on recent statistical evidence on the effect of globalization on environmental objectives). For an industry-specific concrete example of arguably best environmental practices in the consumer retail sector, see Michael Barbaro \& Felicity Barringer, Wal-Mart To Seek Savings In Energy, N.Y. TimeS, Oct. 25, 2005, at C1 (reporting Wal-Mart's chief executive's announcement of "a set of sweeping, specific environmental goals to reduce energy use in its stores, double its trucks' fuel efficiency, minimize its use of packaging and pressure thousands of companies in its worldwide supply chain to follow its lead" and that "the nation's largest retailer is joining the nation's largest manufacturer, General Electric, in pursuing policies that set specific goals for environmental performance, while advertising those goals to shareholders and customers and the public as strategic business decisions"). 
12. International Cooperation in Improving the Human Face of Globalization at an Optimal Rate

The fact is that globalization has a human face: In every part of the planet human beings are realizing real economic gains for their work and skills in helping to create and deliver goods and services which are competitive on a world-class basis. ${ }^{296}$ Of course, we can do better. We can do better by urging poor countries to diversify their economies into multiple labor-intensive industries while avoiding import substitution strategies and replacing excessive bureaucracy with competitive markets. ${ }^{297}$ We can do better by seeing that poor countries implement virtuous social policies - such as literacy programs and higher education initiatives that work in tandem with sensible economic policies to better peoples' lives. ${ }^{298}$ We can do better by designing institutional mechanisms that allow people to cope with the sometimes wrenching changes brought on by globalization and by being mindful of the rate of optimal policy changes to avoid a worst-case scenario like Russia's attempt to plunge headlong into a free market, globalized economy. ${ }^{299}$

The nations of the world can also seek to improve the quantity and quality of their multinational cooperation in addressing trade and environmental disputes. Trade sanctions in the name of environmental justice should not be anathema. ${ }^{300}$ Rather, multinational cooperation on improving environment impacts of expanded trade should focus on technical assistance and foreign aid. Moreover, countries should be free to impose nondiscriminatory environmental rules and taxes on products based on the content and negative impact of their mass consumption. ${ }^{301}$ Indeed, international cooperation and problem solving is more often than not the answer to global environmental issues, not national sovereignty. National policies are often the obstacles, not the solutions, to these global environmental concerns. ${ }^{302}$

296. See supra notes 43-44, 106, 231 and accompanying text (discussing globalization's benefits to humans).

297. See supra note 106 and accompanying text (discussing poverty aspects of globalization).

298. Id.

299. See supra note 105 and accompanying text (noting careful steering and optimal speed of policy changes are necessary to avoid excessively rapid reforms such as those that devastated Russia).

300. See supra notes 238-42 and accompanying text (noting that certain trade restrictions would likely increase unemployment and poverty and reduce economic growth).

301. See supra notes 260-61 and accompanying text (discussing the importance of international cooperation in achieving environmental goals).

302. See supra notes 145-48 (stating national sovereignty is an obstacle in dealing with 
This principle - optimally improving the human face of globalization through international cooperation - is abstract in large measure. Still, there are specific policies that the international community can pursue, as discussed above, to ameliorate trade and the environment disconnects.

\section{Blue and Green Canons}

At this point on our funnel of pragmatism the modes of inquiry are very abstract in nature. WTO dispute panels - as well as bilateral or regional trade agreement dispute tribunals - should utilize a "blue canon" of construction as the basic legal standard. A blue canon of construction calls for as much unrestricted free trade as is reasonably feasible. A blue canon of construction - inspired by the blue image of the borderless earth floating in space when viewed from afar-should be the predominant standard of review. Yet, because of the vital importance of environmentally protective laws, international trade dispute bodies should concomitantly interpret national and international environmental laws that attempt to restrict free trade to allow as much environmental protection as is reasonably feasible. ${ }^{303}$

\section{Employ a Limited and Nuanced Precautionary Principle}

While the precautionary principle of environmental law is, in general, a worthwhile idea, the devil is in the details. The international community should not allow this principle - in the absence of good scientific evidence - to be used by nations, at their sole discretion, to exclude imports. Instead of countenancing unilateral invocation of the precautionary principle by an importing country, we should insist that an international panel of experts judge the merits of a purported importing nation's trade barrier precautionary standard. ${ }^{304}$ In a related way, we should limit the precautionary principle by a reasonable sense of causation that reflects nuance and proportionality. ${ }^{305}$

environmental issues and that international cooperation is necessary).

303. See supra note 72 and accompanying text (noting that a "green" canon of interpretation would urge WTO panel members to construe competing environmental laws as allowing as much environmental protection as is reasonable).

304. See supra notes 253-55 and accompanying text (noting that unilateral declarations of scientific judgment without supporting evidence will never be a viable principle in a rules-based system).

305. See supra notes 4-32 and accompanying text (discussing Peter Singer's call for "an ethical perspective on globalization" and arguing that it lacks nuance and proportionality); see also CASS R. Sunstein, Laws of FeAR: Beyond the Precautionary Principle 109-28 (2005) (discussing how to reconstruct the precautionary principle and manage fear). 


\section{Trade Dispute Tribunals Should Seek Constant Improvement in} Their Legal Processes

It is an extremely abstract principle to urge constant improvement in legal processes. And yet, the very pragmatic, late Harvard law professors, Henry M. Hart, Jr. and Albert M. Sacks, emphasized the social importance of "constant improvement of all of the procedures" which seek to advance "institutional settlement." 306 That is, that "regularized and peaceable methods of discussion . . . ought to be accepted as binding upon the whole society unless and until they are duly changed." ${ }^{307}$ Moreover, the very practical Japanese have a conceptkaizen -which means constant improvement; kaizen has been touted by Japanese business theorists as a vital credo for organizational success. ${ }^{308}$ So the WTO and other international trade tribunals should follow the good, albeit abstract, advice of Professors Hart and Sacks and Japanese business thinkers in pursuing constant improvement in the legal processes by which trade and environment disputes are resolved and institutionally settled.

Still, there are some concrete actions that can serve to leaven this principle. The WTO (and other international trade tribunals) should (1) seek to broaden the expertise of its trade arbitrators to encompass individuals with expertise in environmental, health, and safety, (2) expand panel consultations with international law experts and environmental experts, (3) tighten conflict of interest standards for trade arbitrators, (4) open up trade disputes to amicus input, and (5) consider a supreme trade dispute body and final appeals to the World Court by way of discretionary review. ${ }^{309}$

\section{Appreciate Complexity and Uncertainty}

While extremely abstract in nature, it is useful for those involved in global trade and environment issues to appreciate the complex and often uncertain nature of the beast. We should insist that these important matters be subject to systematic and comprehensive analysis. And yet,

\footnotetext{
306. Henry M. Hart, JR. \& Albert M. SACKS, The Legal Process: BASic Problems IN THE MAKING AND APPLICATION OF LAW 6 (tent. ed. 1958).

307. Id. at 4 .

308. See generally MASAAKI IMAI, KAIZEN: THE Key to JAPAN's COMPETITIVE SUCCESS (1986) (discussing the concept of kaizen).

309. See supra note 73 and accompanying text (discussing suggested methods for WTO reformation).
} 
we should understand and appreciate that proposed solutions can have second-order and feedback consequences. ${ }^{310}$

\section{Tolerate Philosophical Lifestyle Differences}

Most abstract of all on our funnel of pragmatism, is the principle that we should tolerate philosophical lifestyle differences which lead to varying perspectives on the value of globalization. Environmentalists will tend to value environment over income; trade economists and businesspersons will tend to value income over environment. ${ }^{311}$ While it is probably a pipe dream to expect ideological trade bashers to reconcile with ideological environmental bashers, ${ }^{312}$ we can hope that more moderate skeptics of the other camp will continue to sit down with their opponents and bargain in good faith about potential win-win solutions.

In seeking to gain wisdom from this principle we should be attuned to what Professor Pierre Schlag calls a "perspectivist aesthetic": 313

$[T]$ he identities of law and laws mutate in relation to point of view. As the frame, context, perspective, or position of the actor or observer shifts, both fact and law come to have different identities. Accordingly, the social or political identity of the legal actor or observer becomes the crucial situs of law and legal inquiry.

And so, it should come as no surprise that those economic interest groups that stand to be jolted, disrupted, and threatened by more liberalized free-trade proposals will attempt to protect their interests and fight back with whatever rhetorical and legal arguments seem plausible - including environmental rhetoric about how the proposed trade liberalization will detrimentally impact some "green" value. The pragmatic challenge, therefore, of the principle of toleration is to break the impasse of perspectives between free traders and environmentalists. Schlag offers a way of pragmatically breaking the logjam of dueling perspectives through what I have characterized as an "optimistic disassociative aesthetic." 315 As Schlag describes this aesthetic:

\footnotetext{
310. See supra notes 133-34 and accompanying text (discussing characterizations of a pragmatic approach to trade and environment problems).

311. See supra notes $119-21$ and accompanying text (discussing the difference in philosophical thought between economists and environmentalists).

312. See supra notes $235-37$ and accompanying text (distinguishing the no-compromise attitude of WTO bashers with the more moderate attitude of WTO skeptics).

313. Pierre Schlag, The Aesthetics of American Law, 115 HARV. L. REV. 1047, 1051-52 (2002).

314. Id. at 1052.

315. Blomquist, supra note 158, at 504.
} 
[T]o appreciate the ways in which legal identities can collapse into a multitude of associations allows the advocate or judge to reconstruct those identities in desired ways. This breakdown and reconstruction is perhaps the most intense aesthetic moment in law-the point at which the legal professional is creating law. ${ }^{316}$

We might place the recent sage observation of Gene Sperling-a former top economic advisor to President Bill Clinton-into the rubric of an optimistic disassociative aesthetic. Offering comments that describe a potential explanation for both the collapse of WTO trade negotiations in Seattle in 1999 (with environmentalists' protests being a key driver of the collapse) and the November 2005 stall in trade negotiations under the Doha round of trade talks (with farmers' concerns being the main sticking point), Sperling explained that government negotiators of tradeopening pacts must learn to see things from the perspective of those whose "lives and jobs are disrupted by more open trade." 317 In words that are a useful capstone to the pragmatic principle of toleration Sperling asserts:

If you care about progress in market opening, you are going to have to have more ambitious compacts for sharing the downside costs as well as the benefits of open trade .... As economists, we talk about how the benefits of lower prices are broadly shared. But the costs are very heavily concentrated.

\section{CONCLUSION}

Through an analysis of three important environmental critics of globalization (Peter Singer's ethical jeremiad, ${ }^{319}$ Public Citizen's political frontal attack, ${ }^{320}$ and Corey Lofdahl's systems critique ${ }^{321}$ ) coupled with an investigation of three prominent environmental optimists of globalization (Jagdish Bhagwati's plea to cope with and improve globalization, ${ }^{322}$ Jeffrey Frankel's upbeat view on three ways that globalization can be good for the environment, ${ }^{323}$ and Kent Jones's call for long-sighted institutional and cooperative environmental

316. Schlag, supra note 313, at 1098 (emphasis added).

317. Edmund L. Andrews, Farm Issues Stall Talks For a Deal On Trade, N.Y. TIMES, Nov. 10, 2005 , at $\mathrm{C} 1$

318. Id. (internal quotation marks omitted).

319. See supra Part II.A.

320. See supra Part II.B.

321. See supra Part II.C.

322. See supra Part III.A.

323. See supra Part III.B. 
globalization $^{324}$ ), we have discerned a hodgepodge of useful and not so useful ways to think about trade and the environment. Inspired by the model developed by William N. Eskridge, Jr., Philip P. Frickey, and Elizabeth Garrett of a "funnel of abstraction"-which charts a variety of key principles or modes of inquiry when interpreting statutes ${ }^{325}$ - and stimulated by the writings of Daniel A. Farber on eco-pragmatism, ${ }^{326}$ I have developed my own "funnel of pragmatism on global trade and the environment." My funnel of pragmatism consists of seventeen principles or modes of inquiry - distilled from the writings of the six thinkers on trade and the environment in Parts II and III of my Article and leavened by other perspectives - with the most concrete factors at or near the tip of the funnel and the most abstract factors at or near the lip of the funnel. ${ }^{327}$ I have argued that in thinking about issues of global trade and the environment, the most pragmatic and fruitful way to proceed is through a polycentric consideration of both abstract and concrete principles. ${ }^{328}$ By pondering something general and something specific on trade and the environment issues, we can learn to exercise better judgment-call it globoecopragmatism - that will reflect both general standards and factual specifics. In this way, perhaps, we can make further progress in simultaneously opening global markets and protecting the earth's environments.

324. See supra Part III.C.

325. See supra notes $265-71$ and accompanying text.

326. See supra notes 263-64 and accompanying text; see also BryAN G. NORTON, SEARCHING FOR SUSTAINABILITY: INTERDISCIPLINARY ESSAYS IN THE PHILOSOPHY OF CONSERVATION BIOLOGY 9-104 (2003) (discussing pragmatism as an environmental philosophy); THE Jurisdynamics of Environmental Protection: Change and the Pragmatic Voice in ENVIRONMENTAL LAW (Jim Chen ed., 2003) (compiling a series of essays based on the ecopragmatic insights of Professor Farber).

327. See Figure 1, supra notes 271-72 and accompanying text (depicting factors ranging from the most concrete to most abstract inquiry).

328. See supra Part IV.B (discussing seventeen key pragmatic principles). 